\title{
New standards in hypertension and cardiovascular risk management: focus on telmisartan
}

This article was published in the following Dove Press journal:

Vascular Health and Risk Management

19 March 2010

Number of times this article has been viewed

\author{
Domenico Galzerano' \\ Cristina Capogrosso 4 \\ Sara Di Michele ${ }^{2}$ \\ Antonio Galzerano' \\ Paola Paparello' \\ Diana Lama ${ }^{3}$ \\ Carlo Gaudio² \\ 'Department of Cardiology, \\ San Gennaro Hospital, Naples, \\ Italy; ${ }^{2}$ Department of Heart and \\ Great Vessels, A. Reale, La Sapienza \\ University, Rome, Italy; ${ }^{3} \mathrm{~V}$ Division \\ of Internal Medicine, II University, \\ Naples, Italy; ${ }^{4}$ Cardiology Division, \\ San Giovanni Bosco Hospital, \\ Naples, Italy
}

\begin{abstract}
Blockade of the renin-angiotensin system is an important approach in managing high blood pressure, and has increasingly been shown to affect cardiovascular disease processes mediated by angiotensin II throughout the cardiovascular and renal continua. Telmisartan is an angiotensin II receptor blocker (ARB) displaying unique pharmacologic properties, including a longer half life than any other ARB, that result in large and sustained reductions of blood pressure. In patients with mild-to-moderate hypertension, telmisartan has proved superior to other antihypertensive agents (valsartan, losartan, ramipril, perindopril, and atenolol) in controlling blood pressure particularly towards the end of the dosing interval. There is also clinical evidence that telmisartan reduces left ventricular hypertrophy, reduces arterial stiffness and the recurrence of atrial fibrillation, and confers renoprotection. The ONgoing Telmisartan Alone and in combination with Ramipril Global Endpoint Trial (ONTARGET ${ }^{\circledR}$ ) study has demonstrated that telmisartan has similar cardiovascular protective effects to ramipril in a large, high-risk patient population but was better tolerated. The powerful and sustained blood pressure control apparent in clinical trials, together with cardiovascular protection and tolerability demonstrated in ONTARGET ${ }^{\circledR}$ means that telmisartan may be a preferred option for patients with hypertension.
\end{abstract}

Keywords: angiotensin II receptor blocker, cardiovascular disease, hypertension, reninangiotensin system, telmisartan

\section{Introduction}

Angiotensin II, which is generated by the renin-angiotensin system (RAS), plays a pivotal role in hypertension and cardiovascular disease. Thus, pharmacologic regulation of angiotensin II is central to the control of blood pressure and prevention of its pathophysiologic effects on the cardiovascular system, including the kidney and the brain.

The angiotensin-converting enzyme (ACE) inhibitors target one of the enzymes that generate angiotensin II from angiotensin I (Figure 1). However, angiotensin II is not produced exclusively by this mechanism; other enzymes, such as chymase, are also able to generate angiotensin II. ${ }^{1}$ The angiotensin II receptor blockers (ARBs) overcome the detrimental effects of angiotensin II by preventing it binding to the type 1 receptors $\left(\mathrm{AT}_{1}\right)$. This review examines evidence for the efficacy of telmisartan in the treatment of high blood pressure, and explores the body of the evidence that telmisartan prevents disease mediated by angiotensin II throughout the cardiovascular and renal continua.
Correspondence: Domenico Galzerano Department of Cardiology, via Francesco Giordani 42, 80122 Naples, Italy

Tel +390812545179

$\mathrm{Fax}+390812545179$

Email domenicogalzerano@libero.it 


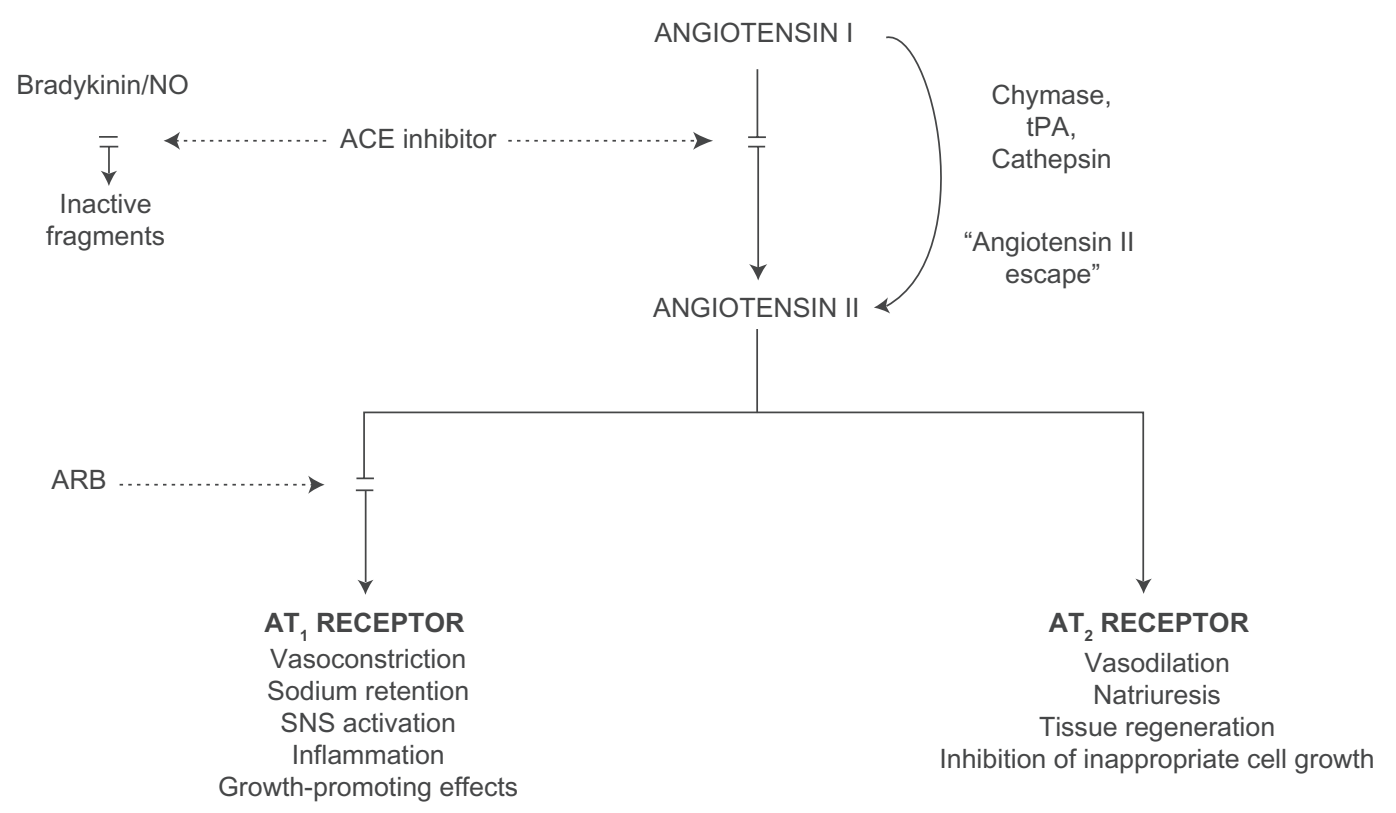

Figure I Mechanism of blockade of the renin-angiotensin system.

Abbreviations: SNS, somatic nervous system; tPA, tissue plasminogen activator.

\section{Pharmacology of telmisartan}

There are currently seven commercially available ARBs, with telmisartan offering unique pharmacologic features compared with the other agents of its class. Telmisartan displays insurmountable, but reversible binding to the $\mathrm{AT}_{1}$ receptor, and it has the highest binding affinity for this receptor among commercially available ARBs. ${ }^{2}$ As well as providing longterm blockade of the $\mathrm{AT}_{1}$ receptor, telmisartan has minimal affinity for the $\mathrm{AT}_{2}$ receptor $(\mathrm{K}>10,000 \mathrm{nM})$ or for acetylcholine, catecholamine, dopamine, histamine, serotonin, or imipramine receptors. ${ }^{3}$ Telmisartan is also highly lipophilic, which facilitates oral absorption and benefits tissue and cell penetration, as demonstrated by its large volume of distribution of approximately $500 \mathrm{~L},{ }^{4,5}$ thereby blocking both systemic and local RAS. Unlike other ARBs, which are excreted to varying extents via the kidneys ${ }^{6,7}$ more than $90 \%$ of telmisartan is eliminated in the feces. ${ }^{8}$ An important distinguishing feature of telmisartan is its long terminal elimination half-life of about 24 hours, suggesting a long duration of action. ${ }^{5}$ It has been shown in healthy volunteers that, at peak plasma concentrations, telmisartan $80 \mathrm{mg}$ reduces the response to exogenous angiotensin II by about $90 \%$, and approximately $40 \%$ inhibition persists for 24 hours. ${ }^{9}$

Telmisartan modulates peroxisome proliferator-activated receptor $\gamma$ (PPAR $\gamma$ ), an established therapeutic target in the treatment of insulin resistance, diabetes, and metabolic syndrome. ${ }^{10}$ It has effects that are characteristic of PPAR $\gamma$ ligands on metabolism. ${ }^{11-14}$ In addition, there is a growing body of evidence that PPAR $\gamma$ activation raises adiponectin production and exerts anti-inflammatory, anti-oxidative and anti-proliferative effects on vascular walls, thus decreasing the risks for atherosclerosis. ${ }^{15,16}$ Although PPAR $\gamma$ activation has been reported for other commercially available ARBs,${ }^{17-19}$ the effects on PPAR $\gamma$ activity have been shown to be considerably weaker than achieved with telmisartan and occur at much higher concentrations. ${ }^{19,20}$ Thus, the unique PPAR $\gamma$-inducing properties of telmisartan, which are achievable at therapeutic doses, may have the capacity for targeting both diabetes and cardiovascular disease.

\section{The importance of sustained blood pressure control}

Hypertension is well recognized as a major risk factor for cardiovascular and renal morbidity and mortality. The importance of blood pressure lowering has been established through epidemiologic and clinical studies, and has led to a broad consensus from guideline bodies on the targets for blood pressure control. Improved control of blood pressure is vital to obtain maximum benefit.

Patients typically prefer to take their medication in the morning. To optimize patient compliance, oncedaily dosing is important. However, for a once-daily drug taken in the morning, early morning is the time of trough efficacy and may pose a problem in the management of hypertension. In one study, approximately $60 \%$ of patients with apparently controlled hypertension when 
measured in the office during the day had, in reality, uncontrolled blood pressure (systolic blood pressure [SBP]/ diastolic blood pressure [DBP] $>130 / 85 \mathrm{mmHg}$ ) determined by ambulatory blood pressure monitoring (ABPM) in the early morning. ${ }^{21}$ An antihypertensive agent's duration of action must be sufficient to control blood throughout the dosing interval and, ideally, if the next dose is delayed or missed. ${ }^{22}$

A further consideration is that, during the morning, incidences of cardiovascular events increase dramatically and are more frequent than at any other time of the day. ${ }^{23-25}$ Blood pressure follows a circadian rhythm, being lowest at night and increasing suddenly in the morning upon awakening. ${ }^{26}$ This early morning blood pressure surge (EMBPS) is caused primarily by orthostatic changes but is also linked to circadian changes in the RAS. ${ }^{27-29}$

\section{Antihypertensive efficacy of telmisartan}

The efficacy of telmisartan in the primary care setting has recently been demonstrated in the MICARDIS ${ }^{\circledR}$ Community Access Trial (MICCAT-2) involving 1619 patients. ${ }^{30}$ The patients had uncontrolled hypertension, 675 having blood pressure that was not controlled despite prior receipt of conventional therapy. The patients in the trial were treated with telmisartan $40 \mathrm{mg}$, titrated to $80 \mathrm{mg}$ or a combination of telmisartan $80 \mathrm{mg}$ plus hydrochlorothiazide (HCTZ) $12.5 \mathrm{mg}$. Office SBP/DBP fell by $22.7 / 12.6 \mathrm{mmHg}$ in the previously untreated patients and by $16.8 / 10.3 \mathrm{mmHg}$ in the previously treated patients. After telmisartan treatment, blood pressure was controlled in $79 \%$ of the patients.

An accurate reflection of the extent of blood pressure control at different stages of the dosing interval is provided by self-measurement of blood pressure in the home or by 24-hour ABPM using an automated device. ${ }^{31}$ In MICCAT-2, ABPM showed that telmisartan alone or in combination with HCTZ produced significant reductions in blood pressure as shown in both day-time and night-time mean SBP/DBP. Furthermore, telmisartan reduced SBP/DBP by $17.2 / 10.1 \mathrm{mmHg}$ in the 4 hours post-awakening in the 95 patients who had an EMBPS of SBP $>30 \mathrm{mmHg} .^{32}$

A large number of clinical studies have demonstrated the antihypertensive efficacy of telmisartan versus other antihypertensive agents. Key studies, as described below, are summarized in Table 1. It should be noted that relative efficacy in fixed-dose studies depends upon the doses employed, which typically related to the doses approved or intended for clinical practice when the study was conducted.
Results should be interpreted with caution in cases where the doses employed are less than the current, clinically-available maximal dose.

\section{Telmisartan versus other ARBs}

In Japanese hypertensive patients, home blood pressure measurement confirmed that telmisartan reduces blood pressure more than other ARBs. ${ }^{33}$ At the lower doses typically used in Japan, once-daily telmisartan 10 to $40 \mathrm{mg}$ taken in the morning achieved greater blood pressure reductions in the early morning than once-daily valsartan 40 to $80 \mathrm{mg}$, candesartan 2 to $12 \mathrm{mg}$, or losartan 25 to $100 \mathrm{mg}$. Comparison of the morning effect on blood pressure versus the evening effect on blood pressure showed that, in particular, the effect of losartan did not persist for 24 hours.

Ambulatory blood pressure monitoring has shown that telmisartan $80 \mathrm{mg}$ confers significantly greater blood pressure lowering than several other ARBs. When compared with valsartan $160 \mathrm{mg}$, telmisartan provided sustained antihypertensive efficacy and superior control of blood pressure during the early morning period. ${ }^{34,35}$ Differences between the treatments were also apparent for seated SBP. This measure was significantly reduced by telmisartan compared with valsartan (12.1 vs $8.2 \mathrm{mmHg}$, respectively; $P=0.0281$ ), while the reduction in DBP was also numerically greater with telmisartan. ${ }^{35}$ Pooled data from two studies showed that, after active therapy, last 6-hour mean DBP was reduced by $7.6 \mathrm{mmHg}$ with telmisartan compared with $5.8 \mathrm{mmHg}$ with valsartan $(P=0.0044)$ and last 6-hour mean SBP was reduced by $11.1 \mathrm{mmHg}$ with telmisartan as opposed to $9.1 \mathrm{mmHg}$ with valsartan $(P=0.0066) .{ }^{35}$ After a dose was deliberately missed, 24-hour mean DBP was reduced by $7.2 \mathrm{mmHg}$ with telmisartan compared with $5.5 \mathrm{mmHg}$ with valsartan $(P=0.0004)$, and the reduction in 24-hour mean SBP after a missed dose was $10.7 \mathrm{mmHg}$ with telmisartan and $8.7 \mathrm{mmHg}$ with valsartan $(P=0.0024)$.

Similarly, 3 ABPM studies comparing telmisartan 40 or $80 \mathrm{mg}$ with losartan 50 or $100 \mathrm{mg}$ demonstrated that telmisartan provided greater reductions than losartan in both the 24-hour mean SBP and DBP and in the in last 6 hours of the dosing interval. ${ }^{36-38}$

There are fewer data comparing the antihypertensive efficacy of telmisartan with ARBs other than valsartan and losartan. A 1-year comparative study in patients with mild hypertension and type 2 diabetes showed that telmisartan produced a superior reduction in blood pressure compared with eprosartan. ${ }^{39}$ Two small-scale clinical studies have compared the blood pressure lowering effects of telmisartan 


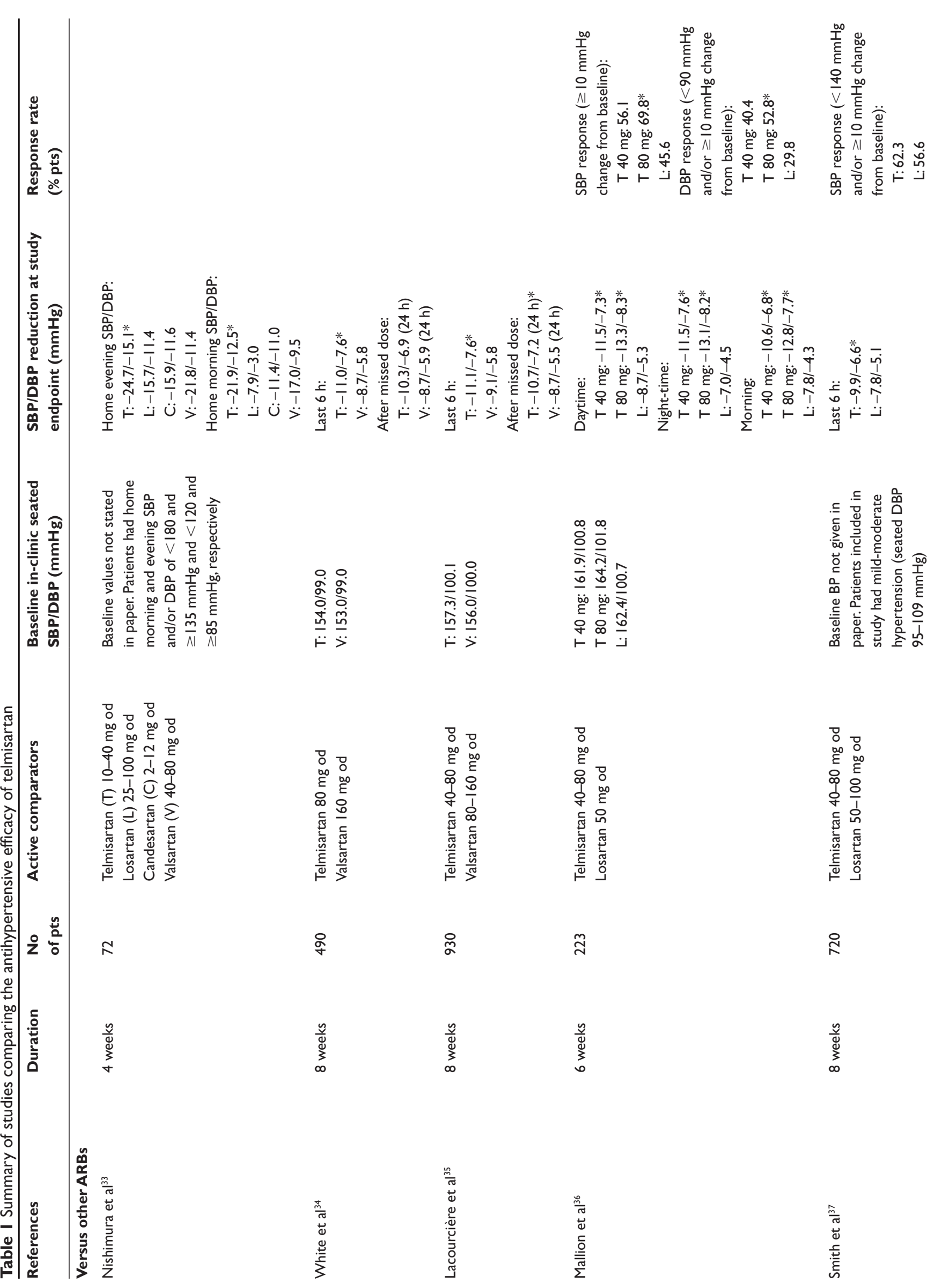



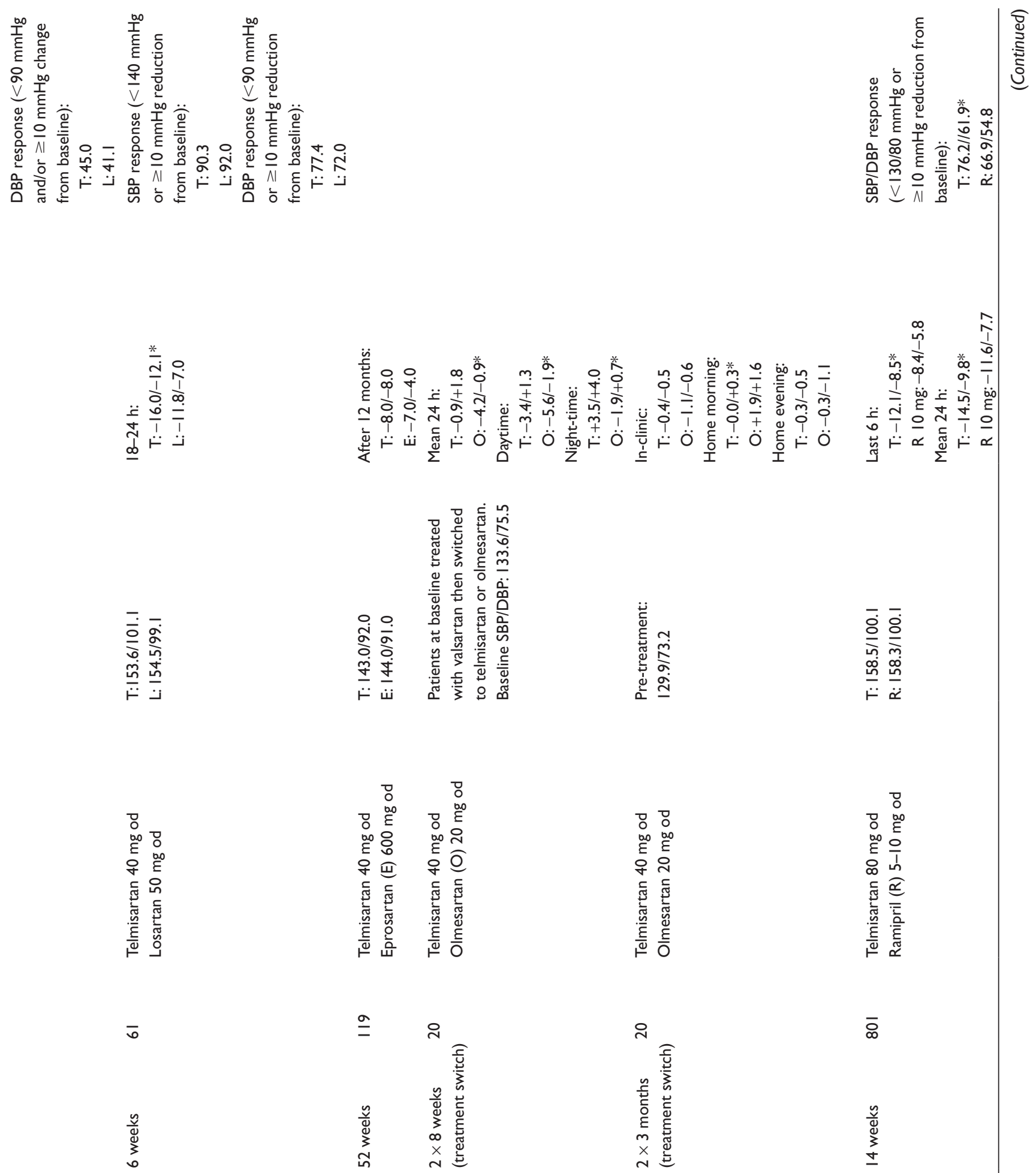

$\bar{\infty}$

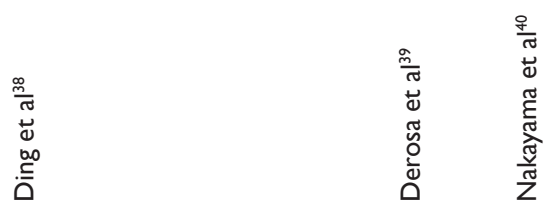

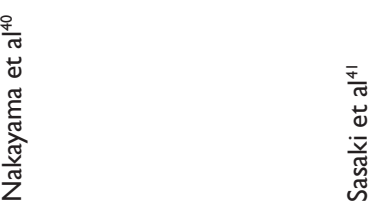

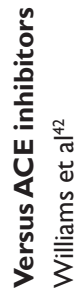




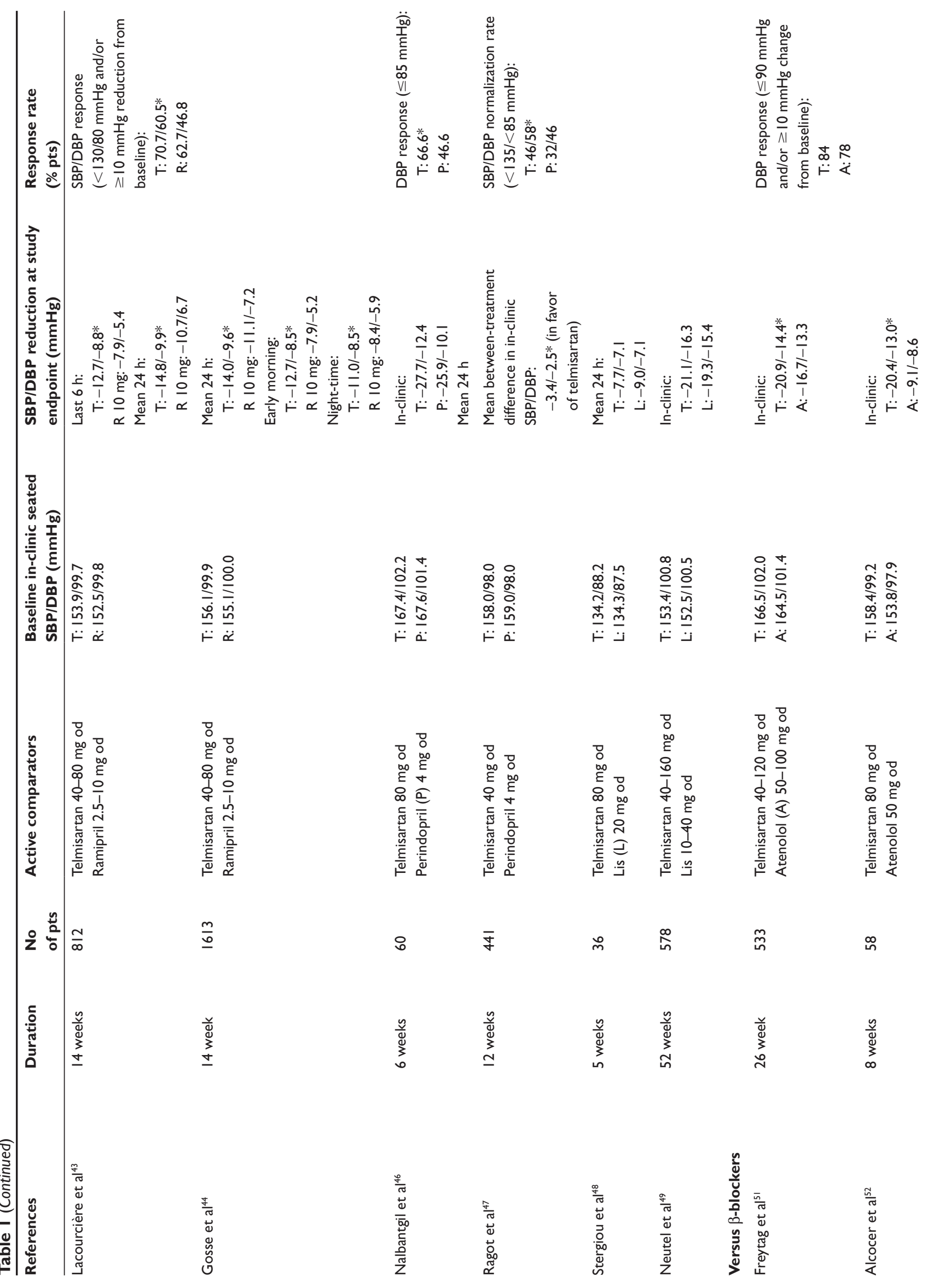



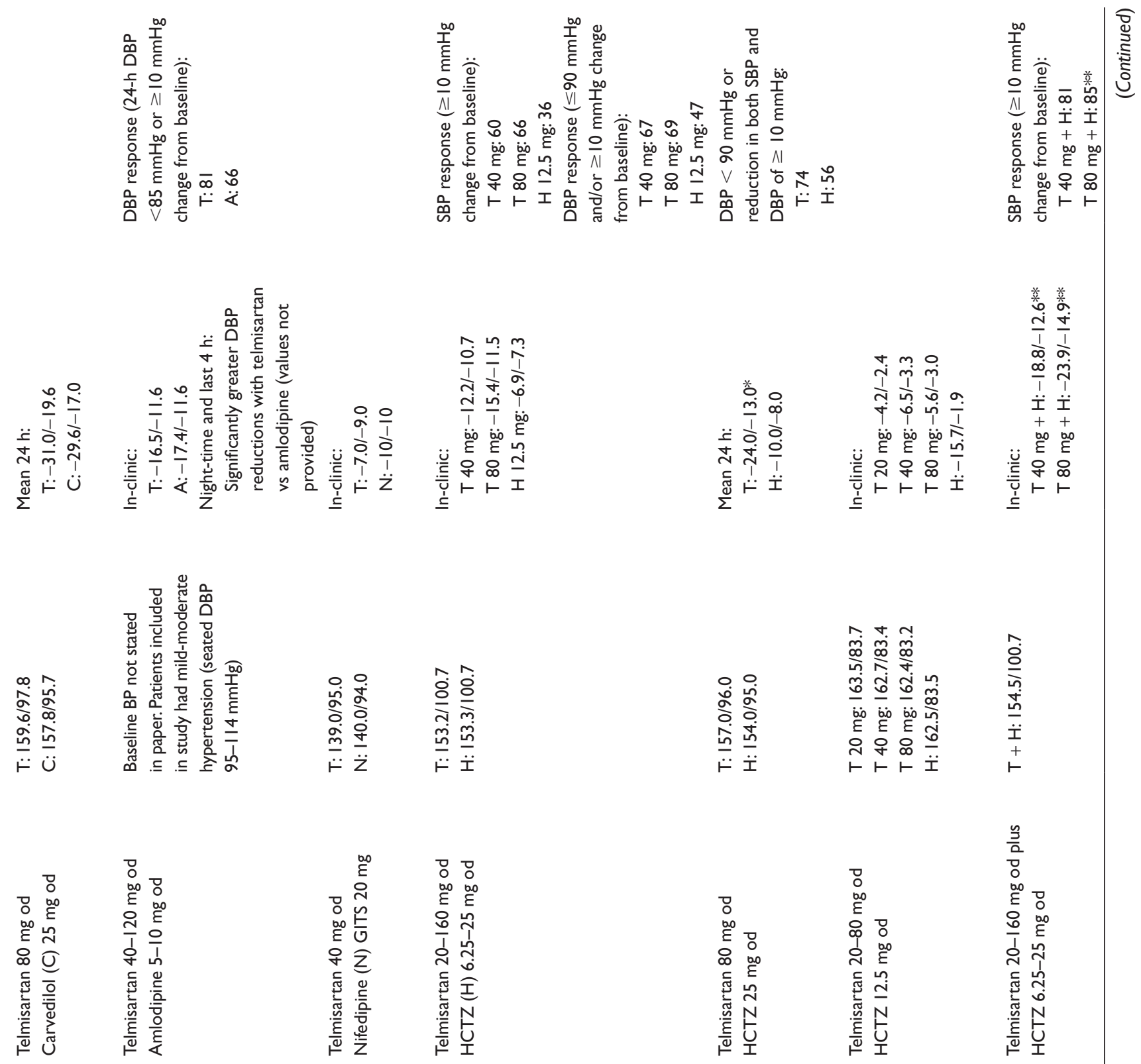

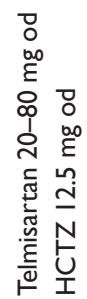

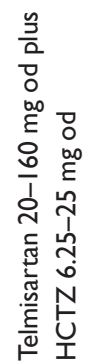

$\infty$

$\tilde{\text { }}$

$\underline{=}$

$\frac{\infty}{\infty}$

a

으

$\frac{\infty}{\infty}$
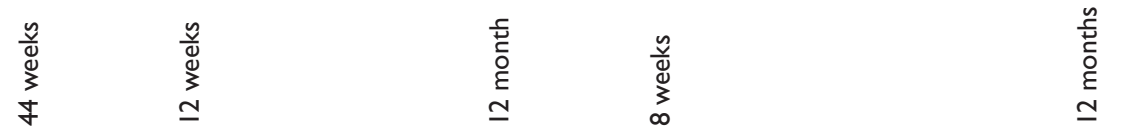

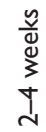
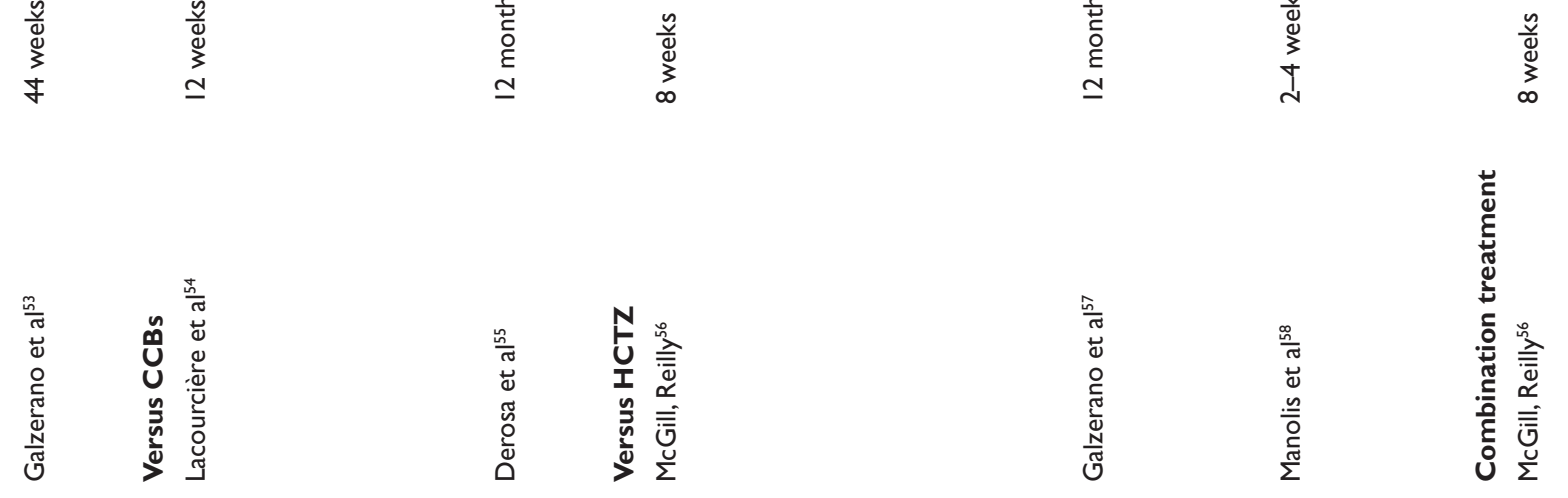


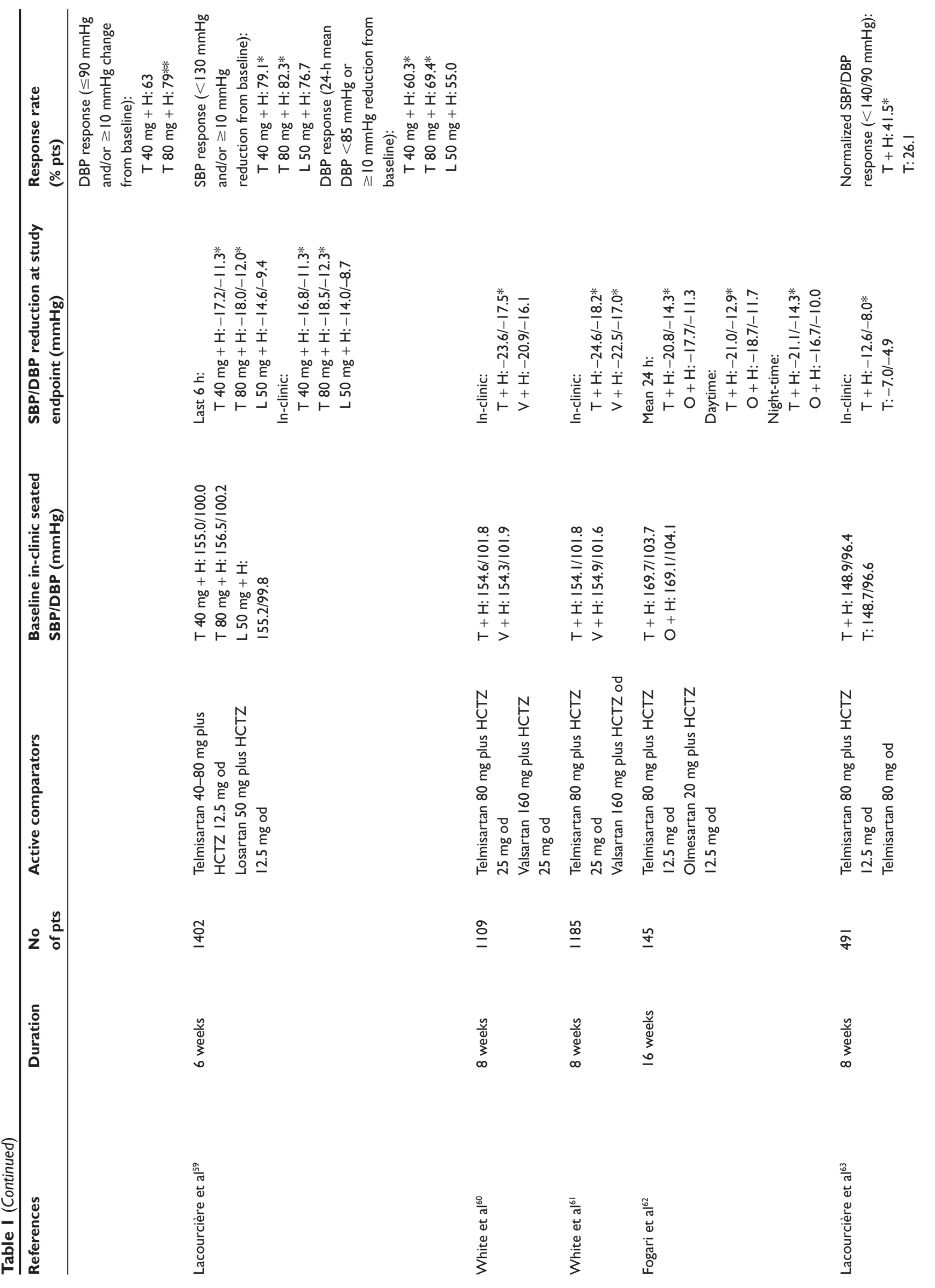



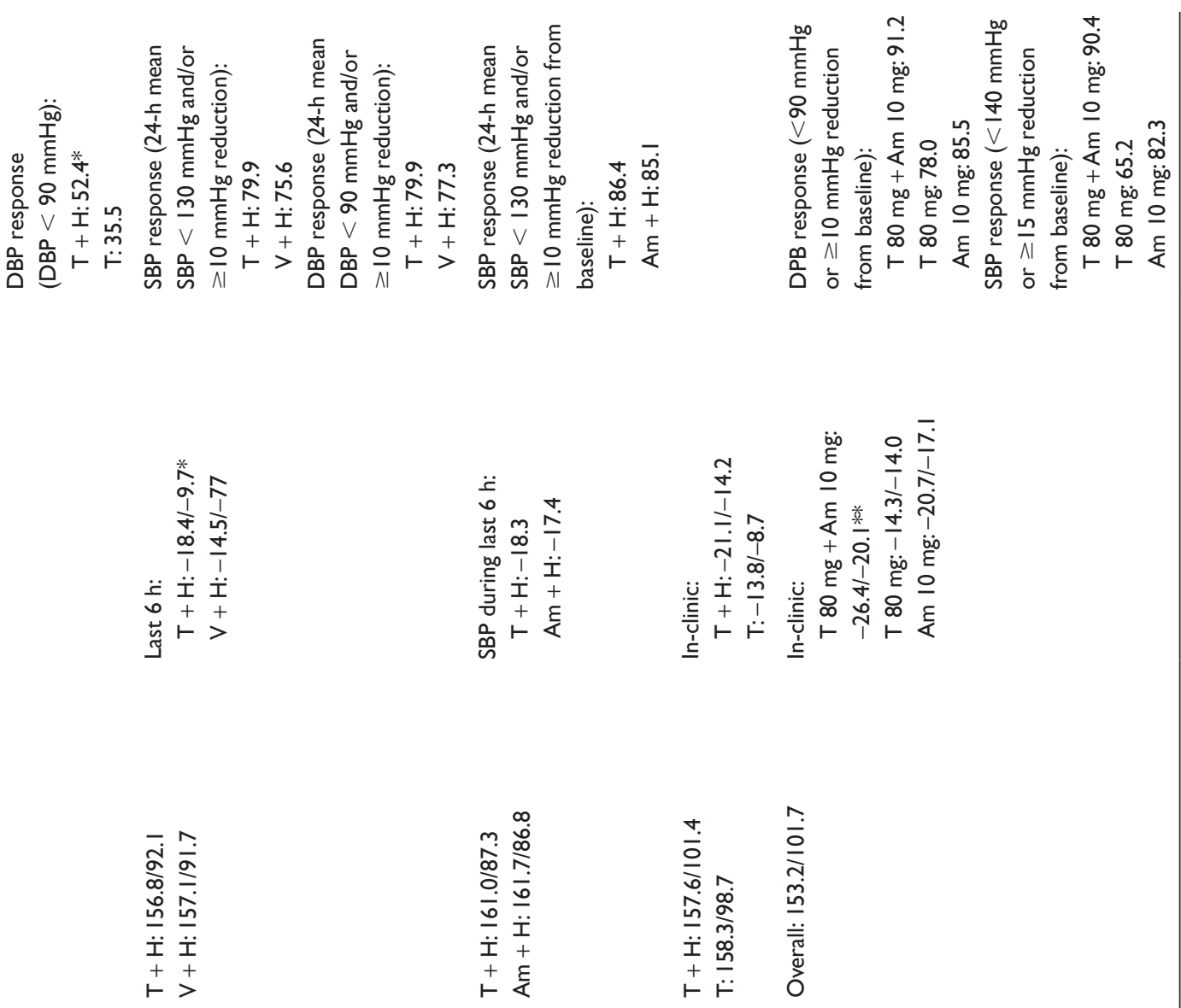

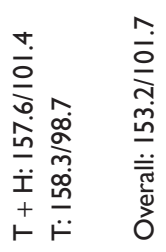
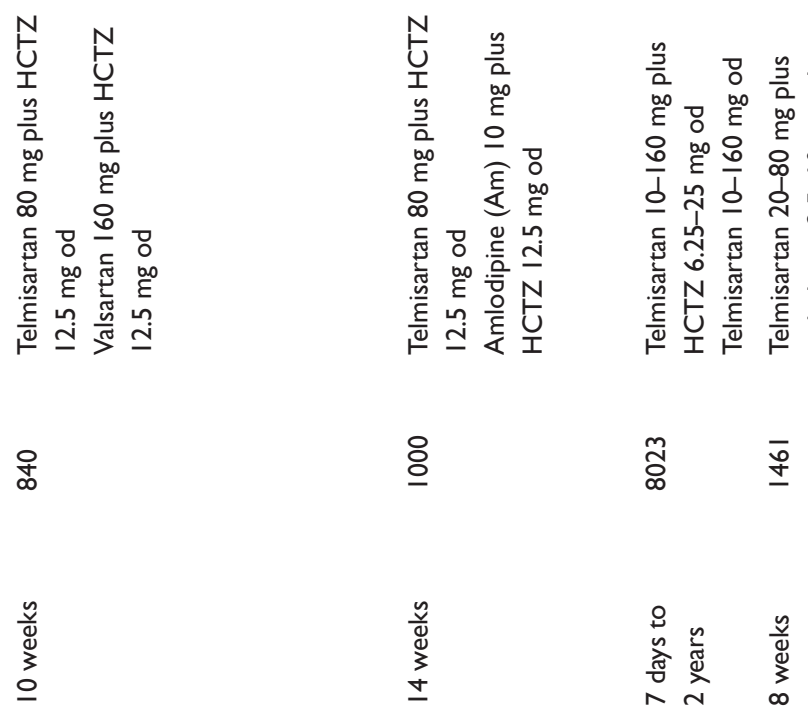

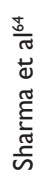
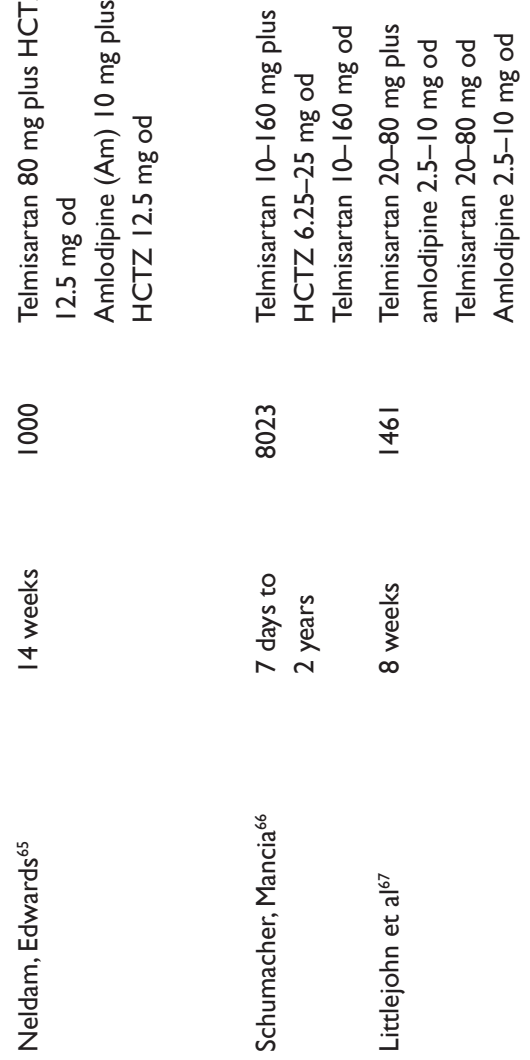

+o

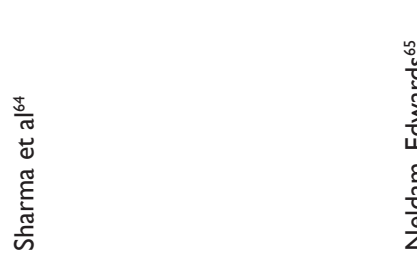

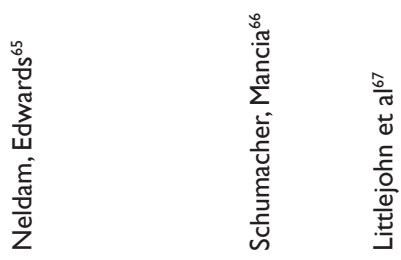

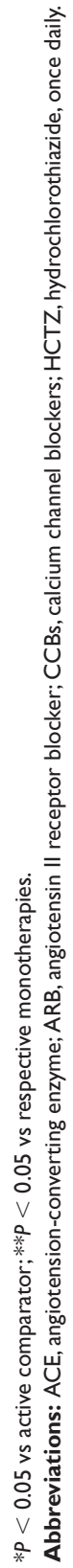


$40 \mathrm{mg}$ versus olmesartan $20 \mathrm{mg}$ in Japanese patients. In one open-label study of 20 patients with early-stage type 2 diabetes and hypertension, olmesartan was shown to provide greater blood pressure reductions than telmisartan. ${ }^{40}$ Conversely, in a separate study, telmisartan was shown to be more effective than olmesartan for controlling early morning blood pressure, in addition to improving glucose and cholesterol levels in patients with hypertension, chronic heart failure and metabolic syndrome. ${ }^{41}$ A PubMed search identified no clinical trials directly comparing the antihypertensive effects of telmisartan versus irbesartan.

\section{Telmisartan versus ACE inhibitors}

Other evidence for telmisartan providing effective blood pressure control comes from two 14-week studies of identical design - Prospective, Randomized Investigation of the Safety and efficacy of MICARDIS ${ }^{\circledR}$ versus ramipril using ABPM (PRISMA ${ }^{\mathrm{TM}}$ ) - conducted in 1613 hypertensive patients in Europe and South Africa (PRISMA ${ }^{\mathrm{TM}} \mathrm{I}$ ) and in the USA and Canada (PRISMA ${ }^{\mathrm{TM}}$ II). In PRISMA $^{\mathrm{TM}}$ I, telmisartan titrated from 40 to $80 \mathrm{mg}$ and given in the morning provided superior blood pressure control than ramipril titrated from 2.5 to 5 to $10 \mathrm{mg}$. ${ }^{42}$ Notably, this difference was observed throughout all periods of the 24-hour dosing interval and resulted in significantly greater reduction in SBP/DBP than ramipril during the last 6 hours $(P<0.001) .{ }^{42}$ Similar results were recorded in PRISMA ${ }^{\mathrm{TM}} \mathrm{II}^{43}$ The pooled analysis of the PRISMA ${ }^{\mathrm{TM}}$ I and II trials documented that 24-h mean SBP/DBP reductions were significantly greater with telmisartan than ramipril (-14.1/-9.6 vs $-11.1 /-7.2$, respectively) and superiority of telmisartan over ramipril was also apparent during the last 6 hours (difference: $4.8 / 3.3 \mathrm{mmHg}$ $(P<0.0001)) .{ }^{44}$ Furthermore, the findings of a meta-analysis of individual data from 1 million patients in 61 prospective studies suggest that the statistically significant greater reduction in last 6-hour mean SBP in patients treated with telmisartan in the PRISMA ${ }^{\mathrm{TM}}$ studies is of clinical relevance in improving long-term prognosis. ${ }^{45}$

The antihypertensive effect of telmisartan was examined in a double-blind comparison of telmisartan $80 \mathrm{mg}$ and perindopril $4 \mathrm{mg}$. Both agents produced similar reductions in 24-hour mean SBP/DBP at the end of the 8-week study. ${ }^{46}$ However, telmisartan provided significantly greater reductions in hourly mean DBP in each of the last 8 hours of the dosing period. Telmisartan $40 \mathrm{mg}$ was also compared with perindopril $4 \mathrm{mg}$ in a 12 -week, open-label study, with the dose being doubled in patients who failed to respond (DBP $\geq 90 \mathrm{mmHg}$ ) at week $6 .{ }^{47}$ Reductions in trough
SBP/DBP from baseline were significantly greater with telmisartan at both 6 and 12 weeks.

Using both 24-hour ABPM and clinic blood pressure measurements, telmisartan $80 \mathrm{mg}$ was found to be as effective as lisinopril $20 \mathrm{mg}$ in reducing SBP and DBP, with telmisartan provide sustained blood pressure control throughout the 24-hour dosing interval. ${ }^{48}$ Higher doses of telmisartan (40, 80, and $160 \mathrm{mg}$ ) and lisinopril (10, 20, and $40 \mathrm{mg}$ ) were compared in another, larger titration-to-response study measuring trough clinic blood pressure and comprising 578 patients who could also receive HCTZ up to a dose of $25 \mathrm{mg} .{ }^{49}$ Control of DBP was similar in patients receiving either telmisartan or lisinopril.

As well as telmisartan generally producing greater reductions in SBP and DBP that were particularly evident towards the end of the dosing period, telmisartan is better tolerated than ACE inhibitors. Comparative studies have consistently shown that incidences of cough were lower with telmisartan than with perindopril, ${ }^{46,47}$ lisinopril, ${ }^{49}$ or ramipril. ${ }^{42,43}$ The ONgoing Telmisartan Alone and in combination with Ramipril Global Endpoint Trial (ONTARGET ${ }^{\circledR}$ ) study, which was an outcome study in a broad cross-section of patients who were at high risk for cardiovascular diseases and who could tolerate ACE inhibitors, the rates of cough and angioedema were significantly lower with telmisartan than with ramipril. ${ }^{50}$ Moreover, telmisartan was associated with better tolerability and greater treatment adherence. The differences in tolerability and adherence between telmisartan and ramipril may well have implications for patients who need long-term treatment to reduce their cardiovascular risk.

\section{Telmisartan versus beta $(\beta)$-blockers}

Beta-blockers have been compared with telmisartan in several studies of short or longer duration. In a titration-toresponse study of 533 patients (with HCTZ added as needed to achieve blood pressure control; mean baseline seated BP $165.8 / 101.8 \mathrm{mmHg}$ ), full $\mathrm{SBP}$ response $(\leq 89 \mathrm{mmHg}$ and/or $\geq 10 \%$ reduction from baseline) was achieved by $84 \%$ of telmisartan-treated patients and $78 \%$ of atenololtreated patients (nonsignificant). ${ }^{51}$ In addition, $80 \%$ achieved $\mathrm{a} \geq 10 \mathrm{mmHg}$ reduction in trough SBP with telmisartan 40 to 80 to $120 \mathrm{mg}$ compared with only $68 \%$ of patients receiving atenolol 50 to $100 \mathrm{mg}(P=0.003) .{ }^{51}$ In addition, telmisartan had the advantage of being better tolerated: over the 26-week study, side effects were experienced by $53 \%$ of patients receiving telmisartan but by $61 \%$ of those treated with the $\beta$-blocker. Most notably, there were fewer incidences of fatigue and male impotence. The superiority of telmisartan 
was also demonstrated in an 8-week open-label comparison of telmisartan $80 \mathrm{mg}$ and atenolol $50 \mathrm{mg}$ in 58 patients. $^{52}$

Telmisartan was compared with carvedilol in a multicenter study on their effects on left ventricular mass (LVM) in patients with mild-to-moderate hypertension..$^{53}$ As part of the study, ABPM was performed at baseline and after 44 weeks' treatment with telmisartan $80 \mathrm{mg}$ or carvedilol $25 \mathrm{mg}$ in 82 patients. The 24-hour mean SBP/DBP reductions were similar in both treatment groups. However, night-time and last 6-hour mean reductions were numerically greater with telmisartan, although statistical significance was not achieved.

\section{Telmisartan versus calcium channel blockers}

When telmisartan $40 \mathrm{mg}$ (titrated to $80 \mathrm{mg}$ at 4 weeks and to $120 \mathrm{mg}$ at 8 weeks for patients whose DBP remained $>90 \mathrm{mmHg}$ ) and amlodipine $5 \mathrm{mg}(5 \mathrm{mg}$ at 4 weeks to $10 \mathrm{mg}$ at 8 weeks for patients whose DBP remained $>90 \mathrm{mmHg})^{54}$ were compared, ABPM demonstrated that both agents produced similar, significant decreases in 24-hour mean SBP/DBP $(P<0.0001)$. Telmisartan, however, was superior to amlodipine with respect to the reductions in DBP at night and during the early morning hours: reduction in DBP in the last 4 hours of the dosing interval was $3.4 \mathrm{mmHg}$ greater with telmisartan than with amlodipine $(P<0.05)$. In addition, a 24-hour mean DBP $<85 \mathrm{mmHg}$ were observed in $71 \%$ of telmisartan-treated patients but only in $55 \%$ of those receiving amlodipine. Telmisartan was also better tolerated: the incidence of adverse events, particularly edema, was lower with telmisartan $(5 \%)$ than with amlodipine $(22 \% ; P=0.05)$.

Another 12-month study, primarily designed to evaluate left ventricular hypertrophy ( $\mathrm{LVH})$, compared the antihypertensive efficacy of telmisartan $40 \mathrm{mg}$ with that of nifedipine gastrointestinal therapeutic system (GITS) $20 \mathrm{mg} .{ }^{55}$ Similar and significant reductions from baseline in SBP/DBP were observed in the two treatment arms.

\section{Telmisartan versus HCTZ}

Telmisartan has been shown to provide more effective control of high blood pressure than HCTZ. In an 8-week factorial study comparing telmisartan $(20,40,80$, or $160 \mathrm{mg})$, 3 doses of HCTZ $(6.25,12.5$, or $25 \mathrm{mg})$ and combinations of these doses, telmisartan 40 and $80 \mathrm{mg}$ resulted in greater reductions in SBP and DBP than HCTZ 12.5 mg. ${ }^{56}$

In a 12-month study to determine the effect of telmisartan and HCTZ on LVH in hypertensive patients, 24-hour ABPM was performed at baseline and after 12 months' double-blind treatment with telmisartan $80 \mathrm{mg}$ or HCTZ $25 \mathrm{mg} .{ }^{57}$ At the end of the study, significant reductions from baseline in 24-hour mean SBP/DBP were detected in both treatment groups, but the blood pressure-lowering effect of 24/13 mmHg with telmisartan versus $10 / 8 \mathrm{mmHg}$ with HCTZ was significantly superior $(P<0.01)$.

Another study was performed in 1039 patients with isolated systolic hypertension. ${ }^{58}$ Trough office SBP was reduced by $15.6 \mathrm{mmHg}$ and $17.9 \mathrm{mmHg}$ in the telmisartan 40 and $80 \mathrm{mg}$ arms after 6 weeks, respectively. This lowering was similar to that of $15.7 \mathrm{mmHg}$ recorded with HCTZ $12.5 \mathrm{mg}$. However, significantly more patients achieved the target reduction in SBP $(<140 \mathrm{mmHg}$ or $>20 \mathrm{mmHg}$ reduction) with telmisartan $80 \mathrm{mg}$ than with HCTZ $12.5 \mathrm{mg}(P=0.03)$.

\section{Combination treatment in difficult-to- treat patients and high-risk populations}

Blood pressure in some patients is ineffectively controlled with monotherapy, and they require a combination of antihypertensive agents to achieve target blood pressure. The combination of telmisartan and HCTZ has been shown to provide greater reductions in blood pressure than either component alone. After a 4-week, placebo run-in period, patients were randomized to receive placebo, telmisartan $20,40,80$ or $160 \mathrm{mg} /$ day, HCTZ 6.25, $12.5 \mathrm{or} 25 \mathrm{mg} /$ day, or one of $12 \mathrm{com}-$ binations of the two agents in a trial involving 818 patients with mild-to-moderate hypertension. ${ }^{56}$ The analysis focused on two combinations: telmisartan $40 \mathrm{mg} / \mathrm{HCTZ} 12.5 \mathrm{mg}$ and telmisartan $80 \mathrm{mg} / \mathrm{HCTZ} 12.5 \mathrm{mg}$. After 8 weeks, telmisartan $80 \mathrm{mg} / \mathrm{HCTZ} 12.5 \mathrm{mg}$ significantly reduced mean supine trough blood pressures by 23.9/14.9 mmHg compared with placebo, which represented a $8.5 / 3.4 \mathrm{~mm} \mathrm{Hg}$ greater decrease than that achieved with telmisartan $80 \mathrm{mg}$ alone and a 17.0/7.7 mmHg greater decrease than HCTZ $12.5 \mathrm{mg}$ alone (both $P<0.01$ ). There was a significant reduction in SBP of $18.8 \mathrm{mmHg}$ with telmisartan $40 \mathrm{mg} / \mathrm{HCTZ} 12.5 \mathrm{mg}$ compared with placebo, and this decrease was significantly greater than that achieved with either monotherapy.

Data from two studies evaluating the combination of telmisartan and HCTZ showed that it produced significantly greater SBP and DBP reductions in the last 6 hours of the dosing interval compared with losartan/HCTZ. ${ }^{59}$ Two studies of identical design have also shown that the fixed-dose combination of telmisartan $80 \mathrm{mg} / \mathrm{HCTZ} 25 \mathrm{mg}$ lowered trough blood pressure to a greater extent than valsartan $160 \mathrm{mg} / \mathrm{HCTZ}$ $25 \mathrm{mg}$ in patients with stages 1 and 2 hypertension. ${ }^{60,61}$ In a comparison of telmisartan $80 \mathrm{mg} / \mathrm{HCTZ} 12.5 \mathrm{mg}$ with olmesartan $20 \mathrm{mg} / \mathrm{HCTZ} 12.5 \mathrm{mg}$, the telmisartan/HCTZ 
combination gave a greater reduction in 24-h blood pressure, and this difference was also seen in daytime and night-time blood pressure values. ${ }^{62}$

There have been several studies that have investigated the combination of telmisartan and HCTZ in patients whose blood pressure is not adequately controlled by telmisartan alone. In one such study, patients whose DBP remained above $90 \mathrm{mmHg}$ after 8 weeks of treatment with telmisartan $80 \mathrm{mg}$ were randomized to telmisartan $80 \mathrm{mg}$ or telmisar$\tan 80 \mathrm{mg} / \mathrm{HCTZ} 12.5 \mathrm{mg}$ for a further 8 weeks. ${ }^{63}$ Greater reductions in blood pressure were achieved with the combination, such that blood pressure had been normalized (defined as SBP $<140 \mathrm{mmHg}$ and DBP $<90 \mathrm{mmHg}$ ) in $41.5 \%$ of patients receiving the combination versus $26.1 \%$ of patients receiving monotherapy.

Patients who are at a particular risk of cardiovascular disease include those who are obese or have type 2 diabetes. It often proves especially difficult to achieve the rigorous control of blood pressure required in these patients. Superior blood pressure lowering of telmisartan $80 \mathrm{mg}$ plus HCTZ $12.5 \mathrm{mg}$, compared with valsartan $160 \mathrm{mg} / \mathrm{HCTZ} 12.5 \mathrm{mg}$ over 24 hours and during the early morning hours was demonstrated in the Study of MICARDIS ${ }^{\circledR}$ on Obese/Overweight Type 2 diabetics with Hypertension $\left(\right.$ SMOOTH $\left.^{\circledR}\right){ }^{64}$

The elderly, another group in which it can be difficult to achieve satisfactory blood pressure control, were recruited into ATHOS $^{\circledR}$ (A comparison of Telmisartan plus HCTZ with amlodipine plus HCTZ in Older patients with predominantly Systolic hypertension). In 1000 patients ( $\geq 60$ years) with isolated systolic hypertension, telmisartan 40 to $80 \mathrm{mg}$ plus HCTZ $12.5 \mathrm{mg}$ was compared with amlodipine 5 to $10 \mathrm{mg}$ plus HCTZ $12.5 \mathrm{mg} .{ }^{65}$ Although there was no significant difference between the two groups in the change from baseline in SBP during the last 6 hours of the dosing interval (which was the primary end point), telmisartan/HCTZ resulted in significantly greater reductions in 24-hours, morning and daytime SBP than amlodipine/HCTZ. The ATHOS study indicates that the combination of telmisartan plus HCTZ provides effective blood pressure control in elderly patients.

A common finding of these studies was that the placebolike tolerability profile of telmisartan was maintained when it was given in combination with HCTZ. In an analysis of 50 trials involving 16,416 patients, the overall incidence of adverse events was low and similar between telmisartan monotherapy and the telmisartan/HCTZ combination. ${ }^{66}$

The combination of telmisartan and amlodipine has also been demonstrated to provide more powerful reductions in blood pressure than monotherapy with either telmisartan or amlodipine. ${ }^{67}$ In a factorial design study, patients with stage 1 or 2 hypertension received placebo, telmisartan (20 to $80 \mathrm{mg}$ ), amlodipine (2.5 to $10 \mathrm{mg}$ ) or a combination of the two agents. The reductions in the in-clinic DBP and SBP observed with the combinations of most clinical interest (40 or $80 \mathrm{mg}$ plus amlodipine 5 or $10 \mathrm{mg}$ ) were all significant. The greatest overall reductions $(-26.4 /-20.1 \mathrm{mmHg})$ were achieved with the telmisartan $80 \mathrm{mg} /$ amlodipine $10 \mathrm{mg}$ combination. This was also associated with the greatest response rates and blood pressure control. In the study, the treatments were well tolerated and, notably, the high incidence of edema with amlodipine $10 \mathrm{mg}$ monotherapy (17.8\%) was reduced by $37 \%$ to $65 \%$ when telmisartan was used in combination. ${ }^{68}$ Therefore, the combination of telmisartan and amlodipine represents a treatment option that delivers large reductions in blood pressure and thereby likely reducing the risk of cardiovascular events.

\section{Cardiovascular protective effects of telmisartan}

The concept of the cardiovascular and renal continua was introduced to explain the pathologic processes connecting risk factors to clinical events of increasing severity and ultimately resulting in end-organ damage and death (Figure 2). Hypertension is one such risk factor. There is a large body of evidence, from ex vivo and in vivo studies to demonstrate that modulation of the RAS with ARBs and ACE inhibitors interferes with several of the pathophysiological mechanisms that lead to target organ damage (TOD), which, if uncontrolled, can be life-threatening.

The cardioprotective properties of ARBs have yet to be determined for all agents in this class and direct comparisons on the effects of ARBs on target organ protection are sparse. Furthermore, within-class comparisons are made difficult given that cardiovascular outcome studies of ARBs have been conducted in very different patient populations, ranging from low risk patients with hypertension (eg, the Losartan Intervention For Endpoint reduction in hypertension [LIFE] $]^{69}$ and Valsartan Antihypertensive Long-term Use Evaluation [VALUE] $]^{70}$ trials) through to patients with severe underlying cardiovascular disease (eg, the Valsartan Heart Failure Trial [ValHeFT], ${ }^{71}$ Candesartan in Heart Failure Assessment of Reduction in Mortality and morbidity [CHARM] trial, ${ }^{72}$ and Valsartan in Acute Myocardial Infarction Trial [VALIANT]). ${ }^{73}$

Current evidence focusing on telmisartan suggest that pleiotropic effects manifest as improvements in endothelial 


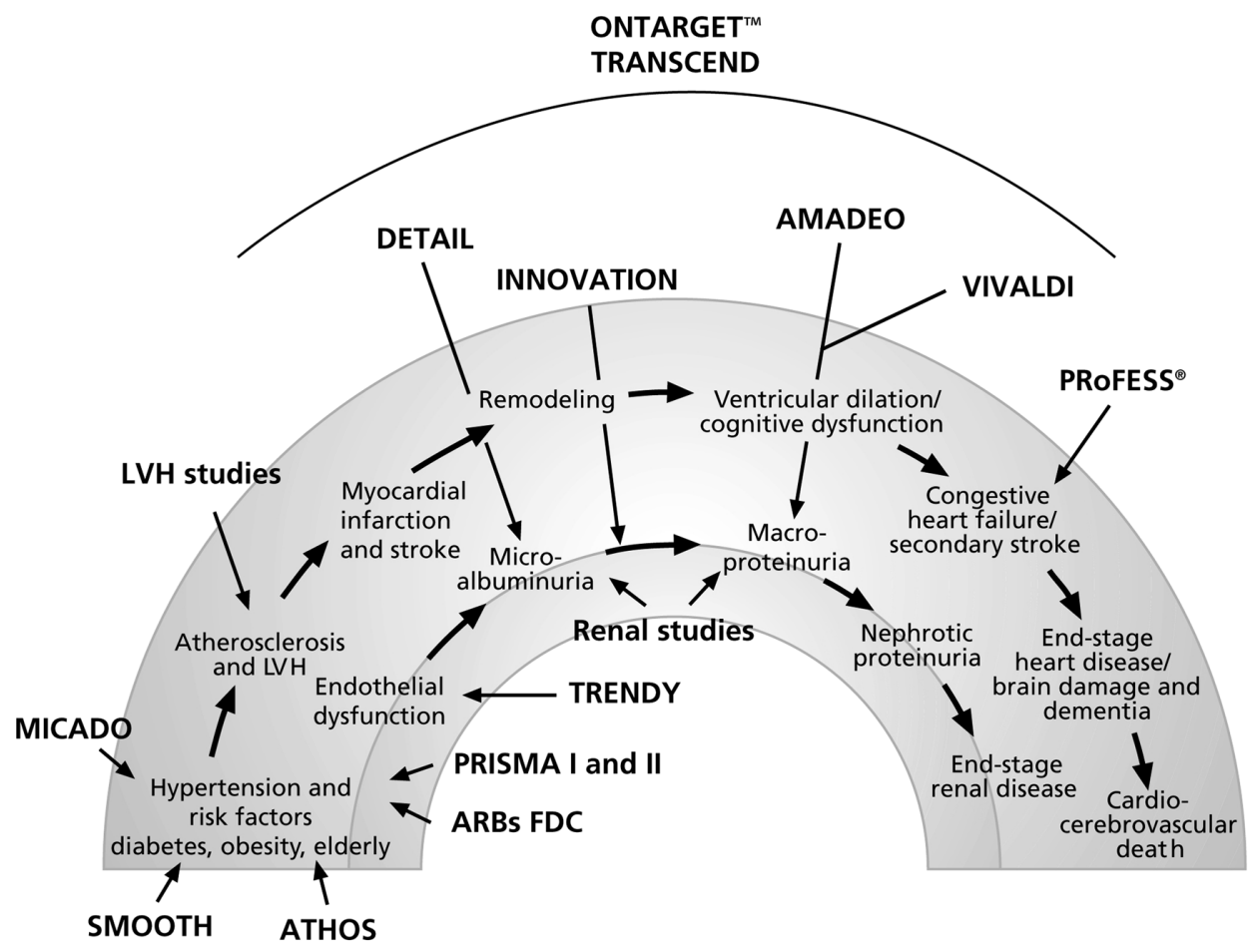

Figure 2 The cardiovascular and renal continua of disease and studies evaluating the efficacy of telmisartan.

Abbreviations: ARB, angiotension II receptor blocker; FDC, fixed-dose combination; LVH, left ventricular hypertrophy.

dysfunction, reductions in $\mathrm{LVH}$, renoprotection in normotensive and hypertensive subjects, improvements in metabolic parameters, and potential benefits in cerebrovascular disease, as discussed below.

\section{Telmisartan and endothelial function}

One mechanism by which telmisartan may prevent TOD is by reducing or reversing endothelial dysfunction, which is one of the first signs of vascular damage and is partly driven by oxidative stress. ${ }^{74}$ Telmisartan reduced superoxide production, nicotinamide adenine dinucleotide phosphate (NADPH) oxidase activity, and markers of oxidative stress in apolipoprotein E-deficient mice. ${ }^{75}$ In addition, telmisartan decreased the size of atherosclerotic lesions. ${ }^{75}$ In spontaneously hypertensive rats, telmisartan expression of NADPH oxidase is reduced and there was increased expression of endothelial nitric oxide synthase, which is likely to contribute to reduced oxidative stress. ${ }^{76}$

Oxidative stress also promotes the accumulation of advanced glycation end (AGE) products. ${ }^{77}$ Together with their cell-surface receptor (RAGE), AGEs are a major cause of the microvascular damage that accompanies the hyperglycemia of diabetes. In cultured endothelial cells, telmisartan prevents angiotensin II-induced upregulation of RAGE expression. ${ }^{78}$ Corroboration for this effect is provided by studies in telmisartan-treated spontaneously hypertensive rats in which the RAGE expression that would normally accompany intraocular age expression did not occur. ${ }^{79}$

Platelet-derived growth factor (PDGF) is a mitogen that is upregulated by oxidative stress and inflammatory stimuli. ${ }^{80}$ It is known to be produced by smooth muscle cells and is one of the most potent growth factors that is involved in the progression of macroangiopathy as seen in diabetes. Telmisartan has been shown to reduce angiotensin II-induced oxidative stress and thereby suppressed the expression of PDGF-B in cultured bovine retinal pericytes. ${ }^{81,82}$

Clinical evidence for improvements in endothelial function with telmisartan is provided by the Telmisartan versus Ramipril in renal ENdothelial DYsfunction (TRENDY ${ }^{\circledR}$ ) study. ${ }^{83}$ Both telmisartan $40 \mathrm{mg}$ and ramipril $5 \mathrm{mg}$ improved endothelial function, assessed by measuring renal plasma flow in response to the infusion of $N^{G}$-monomethyl-1-arginine acetate (1-NMMA), in patients with mild-to-moderate hypertension and normo- or microalbuminuria. Another measure of endothelial function, brachial artery flow-mediated dilation, was improved by $36 \%$ by ramipril $2.5 \mathrm{mg}, 96 \%$ by telmisartan $40 \mathrm{mg}$, and by $111 \%$ with the combination in nonhypertensive patients with well-controlled type 2 diabetes mellitus, but without coronary artery disease, left ventricular dysfunction, or microalbuminuria. ${ }^{84}$ 


\section{Telmisartan and arterial stiffness}

Arterial stiffness is an important risk factor for cardiovascular mortality ${ }^{85}$ and is increased on acute infusion of angiotensin II. ${ }^{86}$ Prior administration of telmisartan significantly attenuated this acute response, as indicated by changes in systemic vascular resistance and the pulse wave stiffness index. ${ }^{87}$ Furthermore, in patients with type 2 diabetes and mildto-moderate hypertension, telmisartan $40 \mathrm{mg}$ for 3 weeks reduced arterial stiffness measured by pulse wave velocity along the carotid-femoral route. ${ }^{88}$ Another study in patients with hypertension suggests that the improvement in pulse wave velocity is greater than predicted on the basis of blood pressure changes. ${ }^{89}$

\section{Metabolic effects of telmisartan}

Vascular risk factors of hypertension, hyperglycemia, and atherogenic dyslipidemia are prevalent abnormalities in subjects with type 2 diabetes. Diabetes increases cardiovascular risk to the same extent as a prior myocardial infarction (MI) in a nondiabetic subject. ${ }^{90}$

Studies in hypertensive patients have shown consistently that telmisartan improves insulin sensitivity and lipid profiles. For example, in patients with type 2 diabetes (managed with diet and exercise) and mild hypertension, telmisartan $40 \mathrm{mg}$ was significantly more effective than eprosartan $600 \mathrm{mg}$ in reducing low-density lipoprotein (LDL)-cholesterol, total cholesterol, and triglycerides. ${ }^{39}$ In another study conducted in patients with type 2 diabetes treated with oral hypoglycemics, telmisartan $40 \mathrm{mg}$ produced significantly greater reductions than nifedipine GITS $20 \mathrm{mg}$ in LDL-cholesterol and total cholesterol. ${ }^{55}$ The effects of telmisartan on lipid parameters have been also been observed in smaller study ${ }^{91}$ and in a post-marketing surveillance study in which people with and without diabetes were treated with telmisartan 40 to $80 \mathrm{mg}$ for at least 1 year. ${ }^{92}$ In the latter study, triglycerides were reduced by $17.4 \mathrm{mg} / \mathrm{dL}$ and cholesterol by $16.4 \mathrm{mg} / \mathrm{dL}$ in the population as a whole and were $22.7 \mathrm{mg} / \mathrm{dL}$ and $23.8 \mathrm{mg} / \mathrm{dL}$, respectively, in patients with hypercholesterolemia. Among patients with diabetes, the reductions were $22.7 \mathrm{mg} / \mathrm{dL}$ and $17.4 \mathrm{mg} / \mathrm{dL}$, respectively.

Telmisartan has been demonstrated to improve markers of glycemic control, such as glycosylated hemoglobin ${ }^{93,94}$ and insulin ${ }^{91}$ in patients with type 2 diabetes. Reductions in insulin resistance with telmisartan have also been demonstrated in nondiabetic subjects. ${ }^{95,96}$ Moreover, telmisartan $80 \mathrm{mg}$ lowered insulin resistance, as measured by the homeostasis model assessment method, to a significantly greater extent than losartan $50 \mathrm{mg}$ in hypertensive patients with metabolic syndrome. ${ }^{97}$ Free plasma glucose, glycosylated hemoglobin and response to the oral glucose tolerance test were also significantly improved by telmisartan.

\section{Telmisartan in renal impairment}

The progression of renal disease can be halted by RAS blockade mediated through reductions in glomerular pressure and through decreased inflammation and oxidative stress. Evidence for the renoprotective effect of telmisartan comes from studies that together have demonstrated positive benefits on renal function in the renal continuum from endothelial dysfunction through to reductions in macroalbuminuria.

In the TRENDY ${ }^{\circledR}$ study, telmisartan not only improved renal endothelial function in patients with type 2 diabetes but also preserved renal function. ${ }^{83}$ In comparison with ramipril, telmisartan significantly improved resting renal plasma flow, renal vascular resistance, and lowered albuminuria.

The Diabetics Exposed to Telmisartan And enalaprIL $\left(\right.$ DETAIL $^{\circledR}$ ) study showed the long-term benefit of telmisartan in patients with type 2 diabetes and either micro- or macroalbuminuria. ${ }^{98}$ Glomerular filtration rate (GFR) declined in the first year with both treatments, but this effect has also been observed with ACE inhibitors and other ARBs, and has been attributed to a hemodynamic effect. ${ }^{99,100}$ Thereafter, the rate of decline was markedly reduced, such that by year 3 , the annual decline in GFR had stabilized to approximately $2 \mathrm{~mL} / \mathrm{min} / 1.73 \mathrm{~m}^{2}$, which is substantially lower than the 10 to $12 \mathrm{~mL} / \mathrm{min} / 1.73 \mathrm{~m}^{2}$ that is typical in untreated diabetics with macroalbuminuria. ${ }^{101}$

Telmisartan has also been shown to reduce albuminuria compared with HCTZ in nondiabetic patients with isolated systolic hypertension ${ }^{102}$ and to reduce microalbuminuria by $69 \%$ over the course of a 12-month, noncomparative study in hypertensive patients. ${ }^{103}$ Other studies confirmed that telmisartan reduced macroalbuminuria in patients with mild and moderate renal failure. ${ }^{104,105}$ The effects of telmisartan on proteinuria may well be additive to those of ACE inhibitors. ${ }^{106}$

Several large-scale clinical studies have been completed that demonstrate the beneficial effects of telmisartan on renal function. The Incipient to Overt: Angiotensin II Blocker, Telmisartan, Investigation on Type 2 Diabetic Nephropathy (INNOVATION ${ }^{\circledR}$ ) study was performed in normotensive, as well as in hypertensive, Japanese patients. ${ }^{107}$ Over a mean of 1.3 years' treatment, both telmisartan 40 and $80 \mathrm{mg}$ significantly reduced transition rates to overt nephropathy in comparison with placebo. Reduced transition rates to overt nephropathy remained after adjustment for changes in SBP 
and in normotensive patients, suggesting telmisartan had a blood pressure-independent effect.

The sister studies, A trial to compare telMisartan $40 \mathrm{mg}$ titrated to $80 \mathrm{mg}$ versus $l o s A r t a n 50 \mathrm{mg}$ titrated to $100 \mathrm{mg}$ in hypertensive type 2 DiabEtic patients with Overt nephropathy $\left(\mathrm{AMADEO}^{\mathrm{TM}}\right)$, and inVestigate the efficacy of MICARDIS ${ }^{\circledR}$ versus VALsartan in hypertensive type 2 DIabetic patients with overt nephropathy (VIVALDI ${ }^{\circledR}$ ) evaluated the effect of telmisartan on macroalbuminuria. In $\mathrm{AMADEO}^{\mathrm{TM}}$, telmisartan reduced urinary protein:creatinine significantly more than losartan after 52 weeks (29\% versus $20 \%$ from baseline, respectively; $P=0.03$ ), despite similar blood pressure control. ${ }^{108}$ This suggests that there are intra-class difference in the renal effects of ARBs, which is consistent with additional properties beyond the blood pressurelowering effect. In VIVALDI ${ }^{\circledR}$, telmisartan $80 \mathrm{mg}$ provided identical reductions in urinary protein excretion $(33 \%$ from baseline) to valsartan $160 \mathrm{mg}$ and there were no significant differences between the two agents in serum creatinine, creatinine clearance, or estimated GFR changes. ${ }^{109}$ These studies suggest that telmisartan may slow the progression of diabetic nephropathy in this group of patients.

\section{Cardiac disease}

The presence of LVH in patients with established hypertension nearly triples the incidence of coronary heart disease and stroke, and increases the incidence of heart failure about seven-fold. ${ }^{110}$ Reducing LVM significantly reduces cardiovascular risk. ${ }^{111}$ Angiotensin II plays a central role in cardiac hypertrophy, causing a trophic response to increased blood pressure and having direct proliferative effects. ${ }^{112}$ The clinical evidence that telmisartan reduces LVM comes from several studies. For example, telmisartan reduced LVM from 151.6 to $135.1 \mathrm{~g} / \mathrm{m}^{2}$, largely due to decreased thickness of the left ventricular wall, in hypertensive patients. ${ }^{113}$ Telmisartan has been compared with other antihypertensives, including diuretics, $\beta$-blockers, ACE inhibitors, and other ARBs. Telmisartan $80 \mathrm{mg}$ proved superior to HCTZ $25 \mathrm{mg}$, with the reduction in LVM being significantly greater with telmisartan for a given percentage change in blood pressure. ${ }^{57}$ Telmisartan $80 \mathrm{mg}$ was more effective in reducing LVM than carvedilol $25 \mathrm{mg}$, despite there being no significant difference in 24-hour mean SBP/DBP reductions between the two treatments. ${ }^{53}$ Addition of telmisartan $80 \mathrm{mg}$ to ramipril $5 \mathrm{mg}$ provided further beneficial effects on LVM, although there were similar reductions in blood pressure with either monotherapy or combination. ${ }^{114}$
A 12-week study showed that replacing twice-daily enalapril $10 \mathrm{mg}$ with once-daily telmisartan 10 to $80 \mathrm{mg}$ does not produce any acute deterioration of exercise capacity or clinical status in patients with mild-to-moderate congestive heart failure (CHF) (New York Heart Association [NYHA] Class II or III and left ventricular ejection fraction $\leq 40 \%$ ). ${ }^{115}$ The study also found no differences in changes of other parameters, such as ejection fraction, NYHA classification, and mean SBP between the treatment groups.

\section{Atrial fibrillation}

ARBs and ACE inhibitors have been shown to be effective in preventing atrial fibrillation in patients with heart failure or left ventricular dysfunction, as seen in the meta-analysis by Healey and colleagues. ${ }^{116}$ The RAS plays an important role facilitating new onset or recurrence of atrial fibrillation. It mediates atrial remodeling by increasing blood pressure, intracavitary atrial pressure, and arrhythmogenic atrial remodeling, by facilitating coronary atherosclerosis and by increasing reactive oxygen substances and favoring atrial fibrosis. Blocking the RAS may prevent left atrial dilatation, atrial fibrosis, dysfunction, and conduction velocity slowing.

There are different clinical scenarios involving prevention of atrial fibrillation in the hypertensive patient (ie, those who have not had any previous episodes of atrial fibrillation, and those with parossistic or persistent atrial fibrillation who either do not need any anti-arrhythmic therapy, or those with persistent atrial fibrillation who do require anti-arrhythmic therapy to maintain sinus rhythm following cardioversion). Previous studies suggest that inhibition of RAS with ARBs or ACE inhibitors may prevent new onset atrial fibrillation in patients without any previous episodes of atrial fibrillation, ${ }^{117}$ and recurrence after cardioversion in hypertensive patients requiring antiarrhythmic therapy. ${ }^{118}$ Previously, we investigated whether telmisartan prevented the recurrence of atrial fibrillation in hypertensive patients who did not require antiarrhythmic therapy. We compared the efficacy of telmisartan and carvedilol in preventing the recurrence of atrial fibrillation in 154 hypertensive patients with a recent history of atrial fibrillation. ${ }^{119}$ There was an atrial fibrillation episode in $14.2 \%(10 / 70)$ of patients who received telmisartan compared with $37 \%$ (23/62) of those receiving carvedilol $(P<0.005)$. In addition to preventing recurrence of atrial fibrillation, the time to a recurrence of atrial fibrillation was longer with telmisartan than with carvedilol. This difference in the rates of new episodes of atrial fibrillation between the agents was not related to changes in blood pressure, left atrial 
size, although a greater left ventricular mass reduction in the telmisartan group was observed. This suggests preventive properties of telmisartan were a pharmacologic effect. It is possible that telmisartan favorably interferes with electrical and structural atrial remodeling in hypertensive patients.

\section{Cerebrovascular disease}

For each $2 \mathrm{mmHg}$ increase in SBP, the risk of stroke is increased by $10 \%{ }^{45}$ Angiotensin II pathways appear not only to be implicated in blood pressure control and body fluid homeostasis, but may also contribute to the pathogenesis of stroke via the stimulation of $\mathrm{AT}_{1}$ receptors. ${ }^{120}$ The use of ARBs may not only prevent the ischemic effect of angiotensin II mediated via $\mathrm{AT}_{1}$ receptors, but also stimulate the unoccupied $\mathrm{AT}_{2}$ receptors with a consequent improvement of brain ischemia. Intra-cerebroventricular infusion of an ARB for 5 days has been shown to induce neuronal regrowth after cerebral ischemia and to reduce expression of transcription factors c-Fos and c-Jun that are associated with programmed cell death and neurodegeneration. ${ }^{121}$ To date, evidence of possible beneficial effects of telmisartan on cerebrovascular disease are provided by studies in animals.

In rats, telmisartan is able to cross the blood-brain barrier and block the effects of centrally administered angiotensin II. ${ }^{122}$ Furthermore, at doses that had no effect on blood pressure, telmisartan delayed the onset of stroke in spontaneously hypertensive, stroke-prone animals. ${ }^{123}$ In cerebral arterioles, telmisartan reversed the vasoconstrictor effect of angiotensin II, changing the response to a vasodilatory one ${ }^{124}$ and overcame the cerebral arterial remodeling occurring in spontaneously hypertensive rats. ${ }^{125}$

Although the effect of telmisartan on stroke has yet to be demonstrated in clinical studies, the effects of telmisartan on cognitive function have been examined in elderly subjects with hypertension. ${ }^{126}$ In addition to providing superior blood pressure control compared with lisinopril $20 \mathrm{mg}$ plus HCTZ, telmisartan $80 \mathrm{mg}$ given with HCTZ $12.5 \mathrm{mg}$ improved performance on cognitive tests significantly more than lisinopril/HCTZ.

\section{Telmisartan outcome trials}

The ONTARGET ${ }^{\circledR}$ program consists of two long-term, largescale, double-blind, multinational outcome studies - the ONTARGET $^{\circledR}$ study $^{50}$ and the parallel Telmisartan Randomized AssessmeNt Study in aCE iNtolerant subjects with cardiovascular Disease (TRANSCEND ${ }^{\circledR}$ ) study. ${ }^{127}$

The ONTARGET ${ }^{\circledR}$ study compared telmisartan $80 \mathrm{mg}$ monotherapy to ramipril $10 \mathrm{mg}$ monotherapy and the combination to ramipril alone. The primary endpoint was a composite of cardiovascular mortality, nonfatal MI, nonfatal stroke, and hospitalization for CHF. Secondary endpoints included newly diagnosed CHF, cardiovascular revascularization, newly diagnosed diabetes, cognitive decline/ dementia, new onset of atrial fibrillation, and nephropathy. ONTARGET ${ }^{\circledR}$ was conducted in patients who could tolerate ACE inhibitor therapy, whereas TRANSCEND ${ }^{\circledR}$ compared telmisartan with placebo in addition to best standard of care in patients intolerant of this class using the same endpoints as ONTARGET ${ }^{\circledR}$.

In the ONTARGET ${ }^{\circledR}$ study, the primary outcome occurred in 1423 patients $(16.7 \%)$ in the telmisartan group, 1412 patients $(16.5 \%)$ in the ramipril group, and in 1386 $(16.3 \%)$ in the combination-therapy group..$^{50}$ Telmisartan was non-inferior to ramipril, and the combination offered no additional protective effect. The results for the secondary outcome of death from cardiovascular causes, myocardial infarction or stroke were consistent with those of the primary outcome.

Even though individuals who were intolerant to ACE inhibitors had been excluded from the trial, 360 patients in the ramipril group stopped their medication because of cough compared with only 93 patients in the telmisartan group. Angioedema resulted in 25 patients discontinuing ramipril compared with 10 patients in the telmisartan group. Rates of cough and angioedema were also higher in the combination group than in the telmisartan group. In the combination group, significantly more patients stopped because of hypotensive symptoms, diarrhea, or renal impairment than in the ramipril group. The incidence of these events was also numerically higher than in the telmisartan group, although no statistics were reported for this comparison.

On the basis of the ONTARGET ${ }^{\circledR}$ results, telmisartan is the only ARB proven to have cardiovascular protective effects in a broad cross section of high-risk patients. It is as effective as ramipril but is associated with less angioedema and cough. The combination offers no additional efficacy advantage compared with the monotherapies. As the authors of the ONTARGET ${ }^{\circledR}$ publication state, the choice between telmisartan and ramipril 'will depend on the preferences of the patients and physicians and the individual's susceptibility to specific adverse events'.

In the TRANSCEND ${ }^{\circledR}$ study, telmisartan was well tolerated among patients who were unable to tolerate ACE inhibitors. Although the reduction in the primary outcome (which included hospitalizations for heart failure) with telmisartan did not achieve statistical significance, it did 
significantly reduce the risk of the composite outcome of cardiovascular death, myocardial infarction, or stroke by $13 \% .{ }^{127}$ Moreover, adherence to telmisartan was high and better in the comparison arm, in which patients received the best standard of care. It is reasonable to assume that the greater tolerability and treatment adherence observed with telmisartan in both ONTARGET ${ }^{\circledR}$ and TRANSCEND ${ }^{\circledR}$ will be of benefit for many patients who are likely to require life-long treatment.

The potential cerebroprotective efficacy of telmisartan was evaluated in the Prevention Regimen For Effectively avoiding Second Strokes $\left(\right.$ PRoFESS $\left.^{\circledR}\right)$ study. ${ }^{128}$ The 4-year study compared telmisartan and placebo on top of usual care, including antihypertensives to control blood pressure, in 20,000 patients with known prior ischemic stroke. The study had a $2 \times 2$ factorial design, with patients also receiving either aspirin plus dipyridamole extended release or clopidogrel alone. The primary outcome was time to recurrent stroke, while secondary outcomes included the onset of vascular events including bleeding events or CHF. There was non significant trend favoring telmisartan over usual care for the primary endpoint. ${ }^{129}$ Exploratory analyses indicate that after excluding the first 6 months of treatment, the incidence of recurrent stroke or major vascular events was significantly lower with telmisartan. The mean treatment period was 2.5 years and a longer treatment period may have allowed the trends that were observed to become significant.

\section{Conclusions}

The pharmacologic features of telmisartan enable it to provide greater and more sustained antihypertensive efficacy than many other antihypertensive agents, and compared with other antihypertensive in other classes, telmisartan is well tolerated. Telmisartan in combination with HCTZ or amlodipine provides greater reductions in blood pressure than the respective monotherapies, and these combinations are well tolerated. The antihypertensive efficacy of telmisartan monotherapy and combinations should translate into increased protection against cardiovascular events. There is also growing evidence that telmisartan and ARBs have beneficial effects on various stages of the cardiovascular and renal continua that may not be solely explained by the lowering of blood pressure. ONTARGET ${ }^{\circledR}$ has shown that telmisartan provides similar cardiovascular protection to ramipril in high-risk patients, while being better tolerated and associated with greater treatment adherence; the latter property is likely to be important in the long-term management of cardiovascular risk.
The attributes of telmisartan and the clinical evidence of its efficacy suggest that it should be one of the preferred options for the treatment of hypertension in mild to moderate hypertensive patients and make it an attractive foundation for use in combination therapy. The findings of both ONTARGET $^{\circledR}$ and TRANSCEND ${ }^{\circledR}$ demonstrate that telmisartan provides a protective benefit when added to other therapies. Its effect on cardiovascular endpoints combined with its proven tolerability suggest that telmisartan could be considered as a potential treatment for patients with vascular disease or high-risk diabetes, irrespective of whether or not they can tolerate ACE inhibitors.

\section{Acknowledgments}

Editorial assistance and journal fees were provided by PAREXEL MMS. This work was supported by Boehringer Ingelheim $\mathrm{GmbH}$.

\section{Disclosures}

The authors disclose no conflicts of interest.

\section{References}

1. Weber MA. Interrupting the renin-angiotensin system: the role of angiotensin-converting enzyme inhibitors and angiotensin II receptor antagonists in the treatment of hypertension. Am J Hypertens. 1999; 12:189S-194S.

2. Kakuta H, Sudoh K, Sasamata M, et al. Telmisartan has the strongest binding affinity to angiotensin II type 1 receptor: comparison with other angiotensin II type 1 receptor blockers. Int J Clin Pharmacol Res. $2005 ; 25: 41-46$.

3. Wienen W, Hauel N, van Meel JC, et al. Pharmacological characterization of the novel nonpeptide angiotensin II receptor antagonist, BIBR 277. Br J Pharmacol. 1993;110:245-252.

4. Wienen W, Entzeroth M, van Meel JCA, et al. A review on telmisartan: a novel, long-acting angiotensin II-receptor antagonist. Cardiovasc Drug Rev. 2000;18:127-156.

5. Stangier J, Su CAPF, Roth W. Pharmacokinetics of orally and intravenously administered telmisartan in healthy young and elderly volunteers and in hypertensive patients. J Int Med Res. 2000;28:149-167.

6. Brunner HR. The new oral angiotensin II antagonist olmesartan medoxomil: a concise overview. J Hum Hypertens. 2002;16(Suppl 2): S13-S16.

7. Burnier M, Brunner HR. Angiotensin II receptor antagonists. Lancet. 2000;355:637-645.

8. Ebner T, Heinzel G, Prox A, et al. Disposition and chemical stability of telmisartan 1-O-acylglucuronide. Drug Metab Dispos. 1999;27: 1143-1149.

9. Stangier J, Su CAPF, van Heiningen PNM, et al. Inhibitory effect of telmisartan on the blood pressure response to angiotensin II challenge. J Cardiovasc Pharmacol. 2001;38:672-685.

10. Pershadsingh HA, Kurtz TW. Insulin-sensitizing effects of telmisartan: implications for treating insulin-resistant hypertension and cardiovascular disease. Diabetes Care. 2004;27:1015.

11. Benson SC, Pershadsingh HA, Ho CI, et al. Identification of telmisartan as a unique angiotensin II receptor antagonist with selective PPAR $\gamma$ modulating activity. Hypertension. 2004;43:993-1002.

12. Fujimoto M, Masuzaki H, Tanaka T, et al. An angiotensin II AT1 receptor antagonist, telmisartan augments glucose uptake and GLUT4 protein expression in 3T3-L1 adipocytes. FEBS Lett. 2004;576:492-497. 
13. Clasen R, Schupp M, Foryst-Ludwig A, et al. PPAR $\gamma$-activating angiotensin type-1 receptor blockers induce adiponectin. Hypertension. 2005;46:137-143.

14. Schupp M, Clemenz M, Gineste R, et al. Molecular characterization of new selective peroxisome proliferator-activated receptor- $\gamma$ modulators with angiotensin receptor blocking activity. Diabetes. 2005;54: 3442-3452.

15. Brody R, Peleg E, Grossman E, et al. Production and secretion of adiponectin from 3T3-L1 adipocytes: comparison of antihypertensive drugs. Am J Hypertens. 2009;22:1126-1129.

16. Nakamura T, Kawachi K, Saito Y, et al. Effects of ARB or ACE-inhibitor administration on plasma levels of adlosterone and adiponectin in hypertension. Int Heart J. 2009;50:501-512.

17. Kappert K, Tsuprykov O, Kaufmann J, et al. Chronic treatment with losartan results in sufficient serum levels of the metabolite EXP3179 for PPAR \{gamma\} activation. Hypertension. 2009;54:738-743.

18. Janke J, Schupp M, Engeli S, et al. Angiotensin type 1 receptor antagonists induce human in-vitro adipogenesis through peroxisome proliferator-activated receptor-gamma activation. J Hypertens. 2006;24:1809-1816.

19. Marshall TG, Lee RE, Marshall FE. Common angiotensin receptor blockers may directly modulate the immune system via VDR, PPAR and CCR2b. Theor Biol Med Model. 2006;1186:1742-1746.

20. Costa FV. Telmisartan: standing out in a crowded contest? High Blood Press Cardiovasc Prev. 2006;13:85-94.

21. Redón J, Roca-Cusachs A, Mora-Macia J. Uncontrolled early morning blood pressure in medicated patients: the ACAMPA study. Analysis of the control of blood pressure using ambulatory blood pressure monitoring. Blood Press Monit. 2002;7:111-116.

22. Iskedjian M, Einarson TR, MacKeigan LD, et al. Relationship between daily dose frequency and adherence to antihypertensive pharmacotherapy: evidence from a meta-analysis. Clin Ther. 2002;24: 302-316.

23. Muller JE, Stone PH, Turi ZG, et al. Circadian variation in the frequency of onset of acute myocardial infarction. $N$ Engl J Med. 1985;313: $1315-1322$.

24. Marler JR, Price TR, Clark GL, et al. Morning increase in onset of ischemic stroke. Stroke. 1989;20:473-476.

25. Elliott WJ. Circadian variation in the timing of stroke onset - a metaanalysis. Stroke. 1998;29:992-996.

26. Millar-Craig MW, Bishop CN, Raftery EB. Circadian variation of blood-pressure. Lancet. 1978;i:795-797.

27. Stern N, Sowers JR, McGinty D, et al. Circadian rhythm of plasma renin activity in older normal and essential hypertensive men: relation with inactive renin, aldosterone, cortisol and REM sleep. J Hypertens. 1986;4:543-550.

28. Casiglia E, Palatini P, Colangeli G, et al. 24 h rhythm of blood pressure and forearm peripheral resistance in normotensive and hypertensive subjects confined to bed. J Hypertens. 1996;14:47-52.

29. Leary AC, Struthers AD, Donnan PT, et al. The morning surge in blood pressure and heart rate is dependent on levels of physical activity after waking. J Hypertens. 2002;20:865-870.

30. White WB, Giles T, Bakris GL, et al. Measuring the efficacy of antihypertensive therapy by ambulatory blood pressure monitoring in the primary care setting. Am Heart J. 2006a;151:176-184.

31. Phillips RA, Weinberg JM. Hypertension 2005: an evidence-based approach to diagnosis and treatment - an American perspective. Expert Rev Cardiovasc Ther. 2005;3:691-704.

32. White WB, Weber MA, Davidai G, et al. Ambulatory blood pressure monitoring in the primary care setting: assessment of therapy on the circadian variation of blood pressure from the MICCAT-2 Trial. Blood Press Monit. 2005;10:157-163.

33. Nishimura T, Hashimoto J, Ohkubo T, et al. Efficacy and duration of action of the four selective angiotensin II subtype 1 receptor blockers, losartan, candesartan, valsartan and telmisartan, in patients with essential hypertension determined by home blood pressure measurements. Clin Exp Hypertens. 2005;27:477-489.
34. White WB, Lacourcière Y, Davidai G. Effects of the angiotensin II receptor blockers telmisartan versus valsartan on the circadian variation of blood pressure: impact on the early morning period. Am J Hypertens. 2004; 17:347-353

35. Lacourcière Y, Krzesinski JM, White WB, et al. Sustained antihypertensive activity of telmisartan compared with valsartan. Blood Press Monit. 2004;9:203-210.

36. Mallion JM, Siché JP, Lacourcière Y; The Telmisartan Blood Pressure Monitoring Group. ABPM comparison of the antihypertensive profiles of the selective angiotensin II receptor antagonists telmisartan and losartan in patients with mild-to-moderate hypertension. J Hum Hypertens. 1999;13:657-664.

37. Smith DH, Cramer MJ, Neutel JM, et al. Comparison of telmisartan versus losartan: meta-analysis of titration-to-response studies. Blood Press Monit. 2003;8:111-117.

38. Ding PY, Chu KM, Chiang HT, et al. A double-blind ambulatory blood pressure monitoring study of the efficacy and tolerability of once-daily telmisartan $40 \mathrm{mg}$ in comparison with losartan $50 \mathrm{mg}$ in the treatment of mild-to-moderate hypertension in Taiwanese patients. Int J Clin Pract Suppl. 2004;58:16-22.

39. Derosa G, Ragonesi PD, Mugellini A, et al. Effects of telmisartan compared with eprosartan on blood pressure control, glucose metabolism and lipid profile in hypertensive, type 2 diabetic patients: a randomized, double-blind, placebo-controlled 12-month study. Hypertens Res. 2004;27:457-464.

40. Nakayama S, Watada H, Mita T, et al. Comparison of effects of olmesartan and telmisartan on blood pressure and metabolic parameters in Japanese early-stage type-2 diabetics with hypertension. Hypertens Res. 2008;31:7-13.

41. Sasaki T, Noda Y, Yasuoka Y, et al. Comparison of the effects of telmisartan and olmesartan on home blood pressure, glucose, and lipid profiles in patients with hypertension, chronic heart failure, and metabolic syndrome. Hypertens Res. 2008;31:921-929.

42. Williams B, Gosse P, Lowe L, et al. The prospective, randomized investigation of the safety and efficacy of telmisartan versus ramipril using ambulatory blood pressure monitoring (PRISMA I). J Hypertens. 2006;24:193-200.

43. Lacourcière Y, Neutel JM, Davidai G, et al. A multicenter, 14-week study of telmisartan and ramipril in patients with mild-to-moderate hypertension using ambulatory blood pressure monitoring. Am J Hypertens. 2006;19:104-112.

44. Gosse P, Neutel JM, Schumacher H, et al. The effect of telmisartan and ramipril on early morning blood pressure surge: a pooled analysis of two randomized clinical trials. Blood Press Monit. 2007;12:141-147.

45. Lewington S, Clarke R, Qizilbash N, et al. Age-specific relevance of usual blood pressure to vascular mortality: a meta-analysis of individual data for one million adults in 61 prospective studies. Lancet. 2002;360:1903-1913.

46. Nalbantgil I, Nalbantgil S, Özerkan F, et al. The efficacy of telmisartan compared with perindopril in patients with mild-to-moderate hypertension. Int J Clin Pract. 2004;58:50-54.

47. Ragot S, Ezzaher A, Meunier A, et al. Comparison of trough effect of telmisartan vs perindopril using self blood pressure measurement: EVERESTE study. J Hum Hypertens. 2002;16:865-873.

48. Stergiou GS, Efstathiou SP, Roussias LG, et al. Blood pressure- and pulse pressure-lowering effects, trough:peak ratio and smoothness index of telmisartan compared with lisinopril. J Cardiovasc Pharmacol. 2003;42:491-496.

49. Neutel JM, Frishman WH, Oparil S, et al. Comparison of telmisartan with lisinopril in patients with mild-to-moderate hypertension. Am J Ther. 1999;6:161-166.

50. ONTARGET Investigators, Yusuf S, Teo KK, et al. Telmisartan, ramipril, or both in patients at high risk for vascular events. $N$ Engl J Med. 2008;358:1547-1559.

51. Freytag F, Schelling A, Meinicke T, et al. Comparison of 26-week efficacy and tolerability of telmisartan and atenolol, in combination with hydrochlorothiazide as required, in the treatment of mild-to-moderate hypertension: a randomized, multicenter study. Clin Ther. 2001;23:108-123. 
52. Alcocer L, Fernandez-Bonetti P, Campos E, et al. Clinical efficacy and safety of telmisartan $80 \mathrm{mg}$ once daily vs. atenolol $50 \mathrm{mg}$ once daily in patients with mild-to-moderate hypertension. Int J Clin Pract Suppl. 2004;58:35-39.

53. Galzerano D, Tammaro P, del Viscovo L, et al. Three-dimensional echocardiographic and magnetic resonance assessment of the effect of telmisartan compared with carvedilol on left ventricular mass a multicenter, randomized, longitudinal study. Am J Hypertens. 2005;18: 1563-1569.

54. Lacourcière Y, Lenis J, Orchard R, et al. A comparison of the efficacy and duration of action of the angiotensin II receptor blocker telmisartan to amlodipine. Blood Press Monit. 1998;3:295-302.

55. Derosa G, Cicero AFG, Bertone G, et al. Comparison of the effects of telmisartan and nifedipine gastrointestinal therapeutic system on blood pressure control, glucose metabolism, and the lipid profile in patients with type 2 diabetes mellitus and mild hypertension: A 12-month, randomized, double-blind study. Clin Ther. 2004;26:1228-1236.

56. McGill JB, Reilly PA. Telmisartan plus hydrochlorothiazide versus telmisartan or hydrochlorothiazide monotherapy in patients with mild to moderate hypertension: a multicenter, randomized, double-blind, placebo-controlled, parallel-group trial. Clin Ther. 2001;23:833-850.

57. Galzerano D, Tammaro P, Cerciello A, et al. Freehand three-dimensional echocardiographic evaluation of the effect of telmisartan compared with hydrochlorothiazide on left ventricular mass in hypertensive patients with mild-to-moderate hypertension: a multicentre study. J Hum Hypertens. 2004;18:53-59.

58. Manolis AJ, Reid JL, de Zeeuw D, et al. Angiotensin II receptor antagonist telmisartan in isolated systolic hypertension (ARAMIS) study: efficacy and safety of telmisartan 20,40 or $80 \mathrm{mg}$ versus hydrochlorothiazide $12.5 \mathrm{mg}$ or placebo. J Hypertens. 2004;22:1033-1037.

59. Lacourcière Y, Neutel JM, Schumacher H. Comparison of fixed-dose combinations of telmisartan/hydrochlorothiazide 40/12.5 $\mathrm{mg}$ and $80 / 12.5 \mathrm{mg}$ and a fixed-dose combination of losartan/hydrochlorothiazide 50/12.5 mg in mild to moderate essential hypertension: Pooled analysis of two multicenter, prospective, randomized, open-label, blindedend point (PROBE) trials. Clin Ther. 2005;27:1795-1805.

60. White WB, Punzi HA, Murwin D, et al. Effects of the angiotensin II receptor blockers telmisartan vs valsartan in combination with hydrochlorothiazide $25 \mathrm{mg}$ once daily for the treatment of hypertension. J Clin Hypertens (Greenwich). 2006;8:626-633.

61. White WB, Murwin D, Chrysant SG, et al. Effects of the angiotensin II receptor blockers telmisartan versus valsartan in combination with hydrochlorothiazide: a large, confirmatory trial. Blood Press Monit. 2008;13:21-27.

62. Fogari R, Zoppi A, Mugellini A, et al. Effectiveness of hydrochlorothiazide in combination with telmisartan and olmesartan in adults with moderate hypertension not controlled with monotherapy: a prospective, randomized, open-label, blinded end point (PROBE), parallel-arm study. Curr Ther Res. 2008;69:1-15.

63. Lacourcière Y, Tytus R, O'Keefe D, et al. Efficacy and tolerability of a fixed-dose combination of telmisartan plus hydrochlorothiazide in patients uncontrolled with telmisartan monotherapy. J Hum Hypertens. 2001;15:763-770.

64. Sharma A, Davidson J, Koval S, et al. Telmisartan/hydrochlorothiazide versus valsartan/hydrochlorothiazide in obese hypertensive patients with type 2 diabetes: the SMOOTH study. Cardiovasc Diabetol. 2007;6:28.

65. Neldam S, Edwards C. Telmisartan plus HCTZ vs amlodipine plus HCTZ in older patients with systolic hypertension: results from a large ambulatory blood pressure monitoring study. Am J Geriatr Cardiol. 2006;16:151-160.

66. Schumacher H, Mancia G. The safety profile of telmisartan as monotherapy or combined with hydrochlorothiazide: a retrospective analysis of 50 studies. Blood Press Suppl. 2008;1:32-40.

67. Littlejohn T, Majul C, Olvera R, et al. Results of treatment with telmisartan-amlodipine in hypertensive patients. J Clin Hypertens. 2009; $11: 1-7$.
68. Littlejohn T, Majul C, Olvera R, et al. Effect of telmisartan addition to amlodipine on reduction of incidence of peripheral oedema: safety analysis from a factorial study in hypertensive patients. $J$ Hypertens. 2008;26(Suppl 1):S460.

69. Dahlof B, Devereux RB, Kjeldsen SE, et al. Cardiovascular morbidity and mortality in the Losartan Intervention For Endpoint reduction in hypertension study (LIFE): a randomised trial against atenolol. Lancet. 2002;359:995-1003.

70. Julius S, Kjeldsen SE, Weber M, et al. Outcomes in hypertensive patients at high cardiovascular risk treated with regimens based on valsartan or amlodipine: the VALUE randomised trial. Lancet. 2004;363:2022-2031.

71. Cohn JN, Tognoni G; for the Valsartan Heart Failure Trial Investigators. A randomized trial of the angiotensin-receptor blocker valsartan in chronic heart failure. $N$ Engl J Med. 345:1667-1675.

72. Pfeffer MA, Swedberg K, Granger CB, et al. Effects of candesartan on mortality and morbidity in patients with chronic heart failure: the CHARM-Overall programme. Lancet. 2003;362:759-766.

73. Pfeffer MA, McMurray JJ, Velazquez EJ, et al. Valsartan, captopril, or both in myocardial infarction complicated by heart failure, left ventricular dysfunction, or both. N Engl J Med. 2003;349:1893-1906.

74. Portaluppi F, Boari B, Manfredini R. Oxidative stress in essential hypertension. Curr Pharm Des. 2004;10:1695-1698.

75. Takaya T, Kawashima S, Shinohara M, et al. Angiotensin II type 1 receptor blocker telmisartan suppresses superoxide production and reduces atherosclerotic lesion formation in apolipoprotein E-deficient mice. Atherosclerosis. 2006;186:402-410.

76. Takai S, Kirimura K, Jin D, et al. Significance of angiotensin II receptor blocker lipophilicities and their protective effect against vascular remodeling. Hypertens Res. 2005;28:593-600.

77. Thornalley PJ. Cell activation by glycated proteins. AGE receptors, receptor recognition factors and functional classification of AGEs. Cell Mol Biol. 1998;44:1013-1023.

78. Nakamura K, Yamagishi S, Nakamura Y, et al. Telmisartan inhibits expression of a receptor for advanced glycation end products (RAGE) in angiotensin-II-exposed endothelial cells and decreases serum levels of soluble RAGE in patients with essential hypertension. Microvasc Res. 2005;70:137-141.

79. Yamagishi S, Takeuchi M, Matsui T, et al. Angiotensin II augments advanced glycation end product-induced pericyte apoptosis through RAGE overexpression. FEBS Lett. 2005;579:4265-4270.

80. Eyries M, Collins T, Khachigian LM. Modulation of growth factor gene expression in vascular cells by oxidative stress. Endothelium. 2004;11:133-139.

81. Amano S, Yamagishi S, Inagaki Y, et al. Angiotensin II stimulates platelet-derived growth factor-B gene expression in cultured retinal pericytes through intracellular reactive oxygen species generation. Int J Tissue React. 2003;25:51-55.

82. Yamagishi S, Amano S, Inagaki Y, et al. Angiotensin II-type 1 receptor interaction upregulates vascular endothelial growth factor messenger RNA levels in retinal pericytes through intracellular reactive oxygen species generation. Drugs Exp Clin Res. 2003;29:75-80.

83. Schmieder RE, Delles C, Mimran A, et al. Impact of telmisartan versus ramipril on renal endothelial function in patients with hypertension and type 2 diabetes. Diabetes Care. 2007;30:1351-1356.

84. Symeonides P, Koulouris S, Triantafyllou K, et al. Favourable pleiotropic effects of ramipril and telmisartan on vascular endothelium of diabetics [abstract]. J Am Coll Cardiol. 2005;45(Suppl A):428A.

85. Laurent S, Boutouyrie $\mathrm{P}$, Asmar R, et al. Aortic stiffness is an independent predictor of all-cause and cardiovascular mortality in hypertensive patients. Hypertension. 2001;37:1236-1241.

86. Wilkinson IB, MacCallum H, Hupperetz PC, et al. Changes in the derived central pressure waveform and pulse pressure in response to angiotensin II and noradrenaline in man. $J$ Physiol. 2001;530:541-550.

87. Vingerhoedt NM, Gilles R, Howes JB, et al. Hemodynamic and pulse wave responses to intravenous infusions of angiotensin II during chronic telmisartan therapy in normal volunteers. J Renin Angiotensin Aldosterone Syst. 2003;4:244-248. 
88. Asmar R, Gosse P, Topouchian J, et al. Effects of telmisartan on arterial stiffness in Type 2 diabetes patients with essential hypertension. $J$ Renin Angiotensin Aldosterone Syst. 2003;3:176-180.

89. Uchida H, Nakamura Y, Kaihara M, et al. Practical efficacy of telmisartan for decreasing morning home blood pressure and pulse wave velocity in patients with mild-to-moderate hypertension. Hypertens Res. 2004;27:545-550.

90. Haffner SM. Risk constellations in patients with metabolic syndrome: epidemiology, diagnosis and treatment patterns. Am J Med. 2006; 119(Suppl 5A):S3-S9.

91. Miura Y, Yamamoto N, Tsunekawa S, et al. Replacement of valsartan and candesartan by telmisartan in hypertensive patients with type 2 diabetes: metabolic and antiatherogenic consequences. Diabetes Care. 2005;28:757-758.

92. Michel MC, Bohner H, Köster J, et al. Safety of telmisartan in patients with arterial hypertension. An open-label observational study. Drug Saf. 2004;27:335-344.

93. Honjo S, Nichi Y, Wada Y, et al. Possible beneficial effect of telmisartan on glycemic control in diabetic subjects. Diabetes Care. 2005; 28:498.

94. Negro R, Hassan H. The effects of telmisartan and amlodipine on metabolic parameters and blood pressure in type 2 diabetic, hypertensive patients. J Renin Angiotensin Aldosterone Syst. 2006a; 7:243-246.

95. Nagel JM, Tietz AB, Goke B, et al. The effect of telmisartan on glucose and lipid metabolism in nondiabetic, insulin-resistant subjects. Metabolism. 2006;55:1149-1154.

96. Benndorf RA, Rudolph T, Appel D, et al. Telmisartan improves insulin sensitivity in nondiabetic patients with essential hypertension. Metabolism. 2006;55:1159-1164.

97. Vitale C, Mercuro G, Castiglioni C, et al. Metabolic effect of telmisartan and losartan in hypertensive patients with metabolic syndrome. Cardiovasc Diabetol. 2005;4:6.

98. Barnett AH, Bain SC, Bouter P, et al. Angiotensin-receptor blockade versus converting-enzyme inhibition in type 2 diabetes and nephropathy. N Engl J Med. 2004;351:1952-1961.

99. Levey AS, Adler S, Caggiula AW, et al. Effects of dietary protein restriction on the progression of advanced renal disease in the Modification of Diet in Renal Disease Study. Am J Kidney Dis. 1996;27: 652-663.

100. Lacourcière $\mathrm{Y}$, Belanger $\mathrm{A}$, Godin $\mathrm{C}$, et al. Long-term comparison of losartan and enalapril on kidney function in hypertensive type 2 diabetics with early nephropathy. Kidney Int. 2000;58:762-769.

101. Parving HH, Andersen S, Jacobsen P, et al. Angiotensin receptor blockers in diabetic nephropathy: renal and cardiovascular end points. Semin Nephrol. 2004;24:147-157.

102. Vogt L, Navis G, Köster J, et al. The angiotensin II receptor antagonist telmisartan reduces urinary albumin excretion in patients with isolated systolic hypertension: results of a randomized, double-blind, placebocontrolled trial. J Hypertens. 2005;23:2055-2061.

103. Redón J, Luque-Otero M, Martell N, et al. Renin-angiotensin system gene polymorphisms: relationship with blood pressure and microalbuminuria in telmisartan-treated hypertensive patients. Phamacogenomics J. 2005;5:14-20.

104. Hannedouche T, Chanard J, Baumelou B, et al. Evaluation of the safety and efficacy of telmisartan and enalapril, with the potential addition of frusemide, in moderate-renal failure patients with mildto-moderate hypertension. J Renin Angiotensin Aldosterone Syst. 2001;2:246-254

105. Cupisti A, Rizza GM, D'Alessandro C, et al. Effect of telmisartan on the proteinuria and circadian blood pressure profile in chronic renal patients. Biomed Pharmacother. 2003;57:169-172.

106. Sengul AM, Altuntas Y, Kurklu A, et al. Beneficial effect of lisinopril plus telmisartan patients with type 2 diabetes, microalbuminuria and hypertension. Diabetes Res Clin Pract. 2006;71:210-219.

107. Makino H, Haneda M, Babazono T, et al. Prevention of transition from incipient to overt nephropathy with telmisartan in patients with type 2 diabetes. Diabetes Care. 2007;30:1577-1578.
108. Bakris G, Burgess E, Weir M, et al. Telmisartan is more effective than losartan in reducing proteinuria in patients with diabetic nephropathy. Kidney Int. 2008;74:364-369.

109. Galle J, Schwedhelm E, Pinnetti S, Böger RH, Wanner C. Antiproteinuric effects of angiotensin receptor blockers: telmisartan versus valsartan in hypertensive patients with type 2 diabetes mellitus and overt nephropathy. Nephrol Dial Transplant. 2008;23: 3174-3183.

110. Kannel WB. Left ventricular hypertrophy as a risk factor in arterial hypertension. Eur Heart J. 1992;13(Suppl D):82-88.

111. Devereux RB, Wachtell K, Gerdts E, et al. Prognostic significance of left ventricular mass change during treatment of hypertension. JAMA. 2004;292:2350-2356.

112. Bouzegrhane F, Thibault G. Is angiotensin II a proliferative factor of cardiac fibroblasts? Cardiovasc Res. 2002;53:304-312.

113. Ivanova OV, Fomicheva OA, Sergakova LM, et al. Angiotensin II receptor blocker telmisartan: Effect on blood pressure profile and left ventricular hypertrophy in patients with arterial hypertension. $J$ Int Med Res. 2005;33(Suppl 1):21A-29A.

114. Petrovic J, Petrovic D, Vukovic N, et al. Ventricular and vascular remodelling - effects of the angiotensin II receptor blocker telmisartan and/or the angiotensin-converting enzyme inhibitor ramipril in hypertensive patients. J Int Med Res. 2005;33(Suppl 1):39A-49A.

115. Dunselman PHJM; and the replacement of angiotensin converting enzyme inhibition (REPLACE) investigators. Effects of the replacement of the angiotensin converting enzyme inhibitor enalapril by the angiotensin II receptor blocker telmisartan in patients with congestive heart failure. Int J Cardiol. 2001;77:131-138.

116. Healey JS, Baranchuk A, Crystal E, et al. Prevention of atrial fibrillation with angiotensin-converting enzyme inhibitors and angiotensin receptor blockers: a meta-analysis. J Am Coll Cardiol. 2005;45: 1832-1839.

117. Wachtell K, Lehto M, Gerdts E, et al. Angiotensin II receptor blockade reduces new-onset atrial fibrillation and subsequent stroke compared to atenolol: the Losartan Intervention For End Point Reduction in Hypertension (LIFE) study. J Am Coll Cardiol. 2005;45: 712-719.

118. Madrid AH, Bueno MG, Rebollo JM, et al. Use of irbesartan to maintain sinus rhythm in patients with long-lasting persistent atrial fibrillation: a prospective and randomized study. Circulation. 2002;106:331-336.

119. Galzerano D, Caselli, S, Breglio R, et al. A multicentre, randomized study comparing efficacy of telmisartan versus carvedilol in preventing atrial fibrillation recurrence in hypertensive patients. Circulation. 2007;116(Suppl II):556-557.

120. Chrysant SG. Possible pathophysiologic mechanisms supporting the superior stroke protection of angiotensin receptor blockers compared to angiotensin-converting enzyme inhibitors: clinical and experimental evidence. J Hum Hypertens. 2005;19:923-931.

121. Dai WJ, Funk A, Herdegen T, et al. Blockade of central angiotensin AT(1) receptors improves neurological outcome and reduces expression of AP-1 transcription factors after focal brain ischemia in rats. Stroke. 1999;30:2391-2398.

122. Gohlke P, Weiss S, Jansen A, et al. AT1 receptor antagonist telmisartan administered peripherally inhibits central responses to angiotensin II in conscious rats. J Pharmacol Exp Ther. 2001;298:62-70.

123. Xu J, Culman J, Blume A, et al. Treatment with telmisartan and lithium of stroke-prone spontaneously hypertensive rats: survival study. Naunyn Schmiedebergs Arch Pharmacol. 2002;365(Suppl 1):R67.

124. Vincent JM, Kwan YW, Lung CS, et al. Constrictor and dilator effects of angiotensin II on cerebral arterioles. Stroke. 2005;36: 2691-2695.

125. Dupuis F, Atkinson J, Liminana P, et al. Comparative effects of the angiotensin II receptor blocker, telmisartan, and the angiotensin-converting enzyme inhibitor, ramipril, on cerebrovascular structure in spontaneously hypertensive rats. J Hypertens. 2005;23: 1061-1066. 
126. Fogari R, Mugellini A, Zoppi A, et al. Effect of telmisartan/ hydrochlorothiazide vs lisinopril/hydrochlorothiazide combination on ambulatory blood pressure and cognitive function in elderly hypertensive patients. J Hum Hypertens. 2006;20:177-185.

127. TRANSCEND ${ }^{\circledR}$ Investigators, Effects of the angiotensin-receptor blocker telmisartan on cardiovascular events in high-risk patients intolerant to angiotensin-converting enzyme inhibitors: a randomised controlled trial. Lancet. 2008;372:1174-1183.
128. Diener HC, Sacco R, Yusuf S. Rationale, design and baseline data of a randomized, double-blind, controlled trial comparing two antithrombotic regimens (a fixed-dose combination of extended-release dipyridamole plus ASA with clopidogrel) and telmisartan versus placebo in patients with strokes: The Prevention Regimen for Effectively Avoiding Second Strokes Trial (PRoFESS ${ }^{\circledR}$ ). Cerebrovasc Dis. 2007;23:368-380.

129. Yusuf S, Diener HC, Sacco RL, et al. Telmisartan to prevent recurrent stroke and cardiovascular events. N Engl J Med. 2008;359:1225-1237.

\section{Publish your work in this journal}

Vascular Health and Risk Management is an international, peerreviewed journal of therapeutics and risk management, focusing on concise rapid reporting of clinical studies on the processes involved in the maintenance of vascular health; the monitoring, prevention and treatment of vascular disease and its sequelae; and the involvement of metabolic disorders, particularly diabetes. This journal is indexed on PubMed Central and MedLine. The manuscript management system is completely online and includes a very quick and fair peer-review system, which is all easy to use. Visit http://www.dovepress.com/ testimonials.php to read real quotes from published authors.

Submit your manuscript here: http://www.dovepress.com/vascular-health-and-risk-management-journal 